〔講識】

\title{
$\mathrm{X}$ 線 分 光 學 (其の狍)
}

大阪帝國大學理學部 濢

（昭和十八年六月二十八日受領）

\section{第回正 X線分光器に用ふる結晶}

\section{6. 分光器用拮蚛の有すべを性能}

X楾分光器に在來用ひられる続晶は此敢的影阴

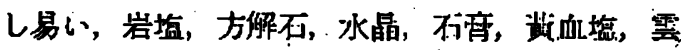

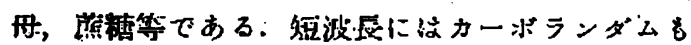

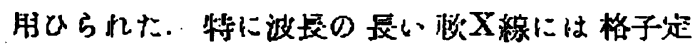

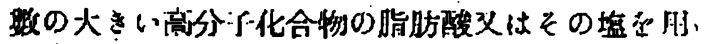

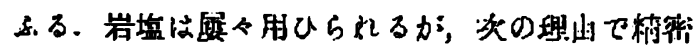

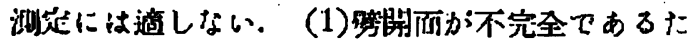
めに，スペクトル線は鮮銳てなく，特に裹分解能

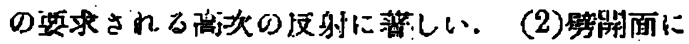

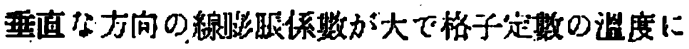

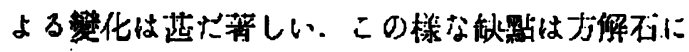
はない。

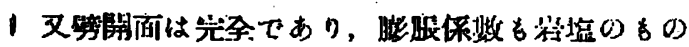

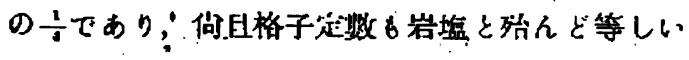

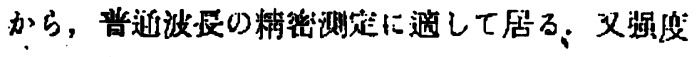
测定の際に，方解石はその反射能が无て波長と 梹に變化せ好から都合が占い。

\section{7. 格子定数の尌算}

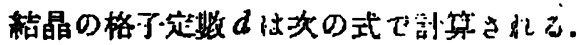

$$
d=\left(\frac{n \cdot M \cdot m}{\rho \cdot V}\right)^{1 / 3}=\left(\begin{array}{c}
n \cdot M \\
\rho \cdot L \cdot V
\end{array}\right)^{1 / 3} .
$$

落に $n=$ 㧘位格于凶の分于-の數

$M=$ 分子量.

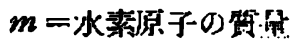

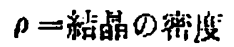

$L=$ Loschmidtu教

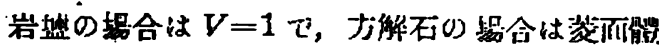

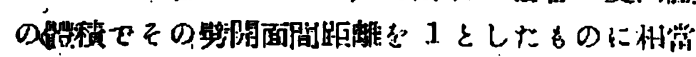
ᄂ

$$
V=\frac{(1+\cos \beta)^{2}}{\sin \beta(1+2 \cos \beta)}
$$

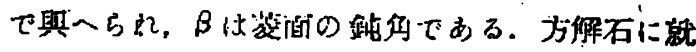

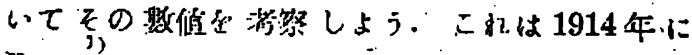

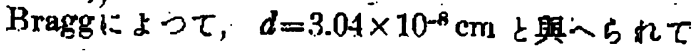

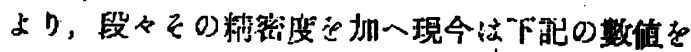

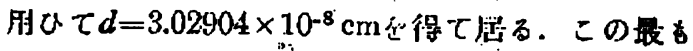

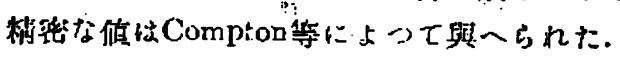

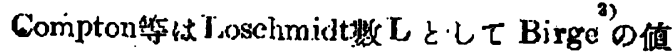

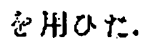

$$
L=\frac{A \cdot c}{10 \cdot E \cdot e}=(6.0594 \pm 0.0063) \cdot 10^{28}
$$

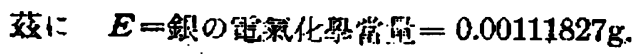

$c=$ 光の速度 $=2.9986 \cdot 10 \mathrm{~cm}-\mathrm{sec}^{-1}$

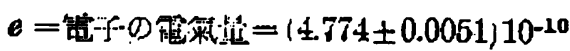

数電單位.

$A=$ 銀の湶子留 $=107.88$

このLの他に, 万解石の翼合に, $20^{\circ} \mathrm{C}$ の佔として

$$
\begin{aligned}
& n=\frac{1}{2}, \quad M=100.075 \pm 0,03 \\
& \rho=2.7102 \pm 0.0004, \quad V=1.09630 \pm 0.00007
\end{aligned}
$$

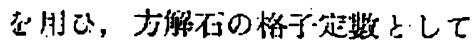

$$
(3.0291 \pm 0.0010) \cdot 10^{-s} \mathrm{~cm}
$$

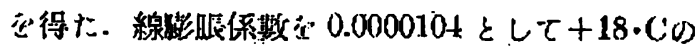
糪として

$$
d=3.02904 \cdot 10^{-\mathrm{s}} \mathrm{cm}
$$

路た。

\section{X線分光學による格子定数の決定}

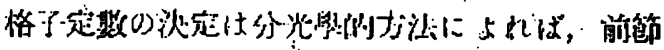

1) W.I. Bragg: Proc. Roy. Soc. A 89 468(1914)

- 2) A.H. Compton, J.I.N, liects, O.K. de Foe; Phys. Rev. 25625 (1925)

3) R.T. Birge: Phys. Rev. 14365 (1810) 


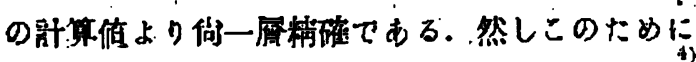

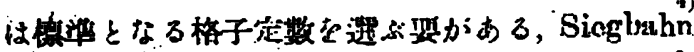

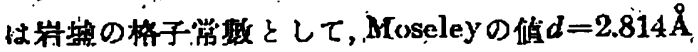

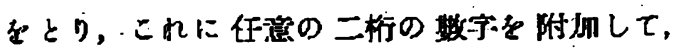
$d=2814.00 \mathrm{X}$ 策你行 $+18^{\circ} \mathrm{C} に \tau$ 正しいるのとし t.

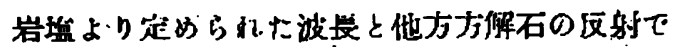
計勧しえた波長とが最るよく合々盛に Biegbahn

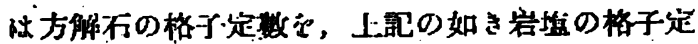

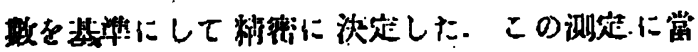

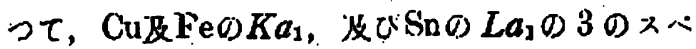

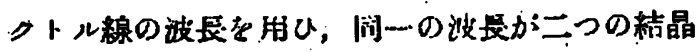

斿 Compton 等が Bragg によって定められた方

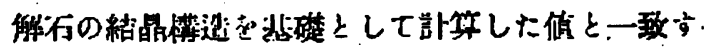
己.

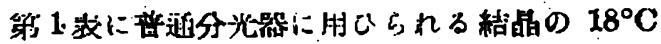
に於ける格了定数要楞げる。

波長の長心顿X線に到しては，光學的格子の他

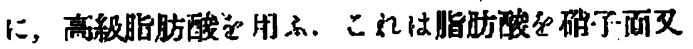

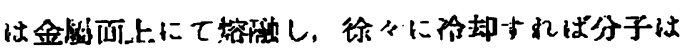
それらの面に平行に規则正しく站ひ，朴営鲜镜な

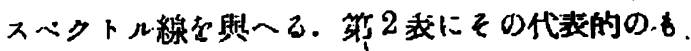

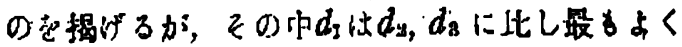

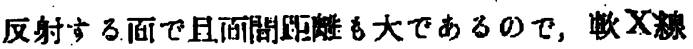

第 1 装

\begin{tabular}{|c|c|c|c|c|c|}
\hline 精 & 反射而 & dh更位 & $\log 2 d$ & 稳喅助你般 $a$ & $x$ \\
\hline 岩 境 $(\mathrm{NaCl})$ & 等 & 2.81400 & $0.7503 i 541$ & $4.04 \times 10^{-5}$ & Siegbahn 1) \\
\hline 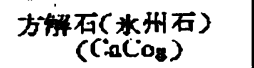 & (10ī1) & 3.02904 & 0.78233347 & $1.04 \times 10^{-5}$ & "I I) \\
\hline " & $n$ & $"$ & $" \prime$ & $1.02 \times 10^{-3}$ & Siegbahn 2) \\
\hline 水 & 样 & $4: 24664$ & 0.0290750 & $3.42 \times 10^{-8}$ & Giegbahn-Dolejsek \\
\hline$"$ & $"$ & 1.21142 & 0.8288995 & $1.04 \times 10^{-0}$ & Siegibahn : 2) Bergqquist' \\
\hline 石荓 $\left(\mathrm{CaSO}_{4} .2 \mathrm{II}_{2} \mathrm{O}\right)$ & $\begin{array}{c}\text { 等盟面 } \\
\text { (0) }\end{array}$ & 7.5776 & 1.1805620 & $2.5 \times 10^{-5}$ & Irjalmar 4j \\
\hline$n$ & & 7.57007 & 1.1806457 & $3.78 \times 10^{-0}$ & - Sieglahnn 2) Friessen \\
\hline 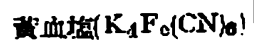 & $(100)$ & 8.408 & 1.222572 & & Moseley 7) \\
\hline 謍 姆 & 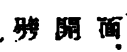 & 9.9250 & 1.29776 & & Larsson 5) \\
\hline & & 9.82758 & $1.29787: 1$ & $1.53 \times 10^{-A^{-1}}$ & Siegbahn 2) \\
\hline 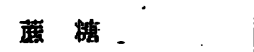 & $(1.00)$ & 10.572 & 1.32512 & & Stenätröm 6) \\
\hline
\end{tabular}

1). M. Sicglahn; Phil. Mag. (6) $37601 ; 38$ 6:9; $38617^{i}$ (1919); Ann: Physik 5956 (1919)

2) M. Siegbahn; "Spektroskopie der Röntgenstrahen"

3) M. Siegbahn, V. Dolejgek : ZS. f. Phys. 10109 (1922)

4) F. Lijalmar; ZS. f. Phys. 1430 (1920)

5) A. Larssin; Ark. f. Mathem. Astr. u. Fysik 10 (A) 14 (1980̈); ZS. f. Phys. 35401 (1426)

6) W. Slenström; Anọ phys. 57347 (1918)

7) H: Moseley; Phil. Mag. 261024 (1913)'.

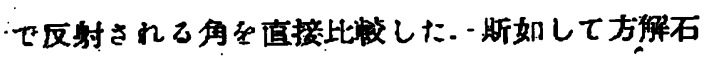
の本均格子定数として

$18^{\circ} \mathrm{C}$ 於 $\tau \quad d=3029,04 X$ 單位。

を得た。この1919年の测定倠は、述の1925年に於。

4) M. Sieghahn : Anon. Physik. 5956 (1919)
に计ひられる.

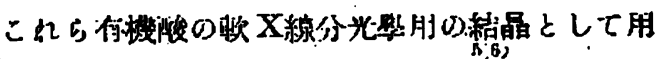
ひ得る可能性に就ての綜合報告がある。

5). J. J. 'Trillat: Ann phys. 65 (1926)

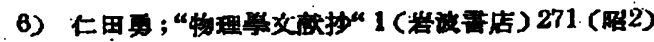


第 2 琵

\begin{tabular}{|c|c|c|c|c|c|}
\hline \multirow{2}{*}{ 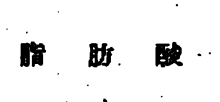 } & \multicolumn{3}{|c|}{ 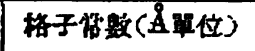 } & & \\
\hline & $\cdot d_{1}$ & $d 2$ & $d x$ & & \\
\hline が & 23.2 & - & - & Mitller & 1) \\
\hline 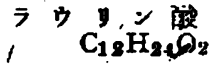 & 27.268 & - & 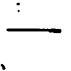 & Thoraeus & 2) \\
\hline 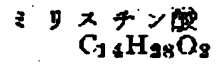 & 32.2 & 4.12 & $3.7 \%$ & Müller & 1) \\
\hline 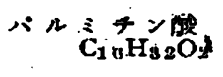 & 34.7 & 4.08 & 3.69 . & ii. & \\
\hline & 35.49 & $\therefore$ & 1 & Thoracus & 2) \\
\hline 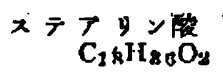 & $: 8.7$ & 4.05 & 3.62 & Müller & 1) \\
\hline
\end{tabular}

1) A. Mũler : Trans. Chem.Soc- 1232043 (1923)

2) R. Thoraeus: Phil. Mag. 1 312 (j926)

\section{9. 格子定数及照射角に数才る溫度の補正}

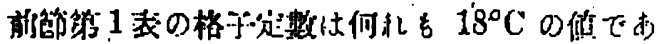

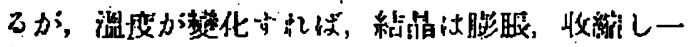

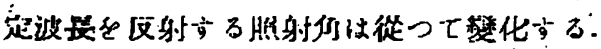

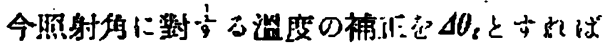

$2 d \sin \theta=n \lambda$

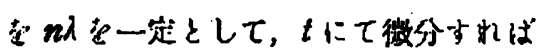

$2 d\left(\cos \theta \cdot \Delta \theta_{l}+\sin \theta \cdot a \cdot \Delta \theta_{\ell}\right)=0$ $\Delta \theta_{t}=-a \tan \theta \cdot \Delta t$

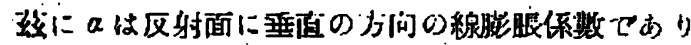

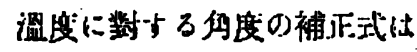

$$
\Delta \theta_{\ell}=a\left(t-18^{\circ}\right) \tan \theta
$$

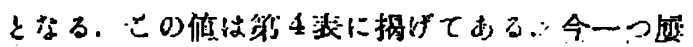
《用认ら机式は炏の如くして整か和る。

$+18^{\circ} \mathrm{C}$ 及 $+t^{\circ} \mathrm{C}\left(t>18^{\circ} \mathrm{C}\right) 0$ 恪了定数及家

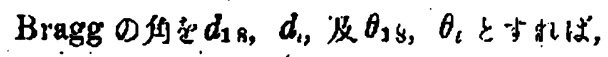

$$
\begin{aligned}
& n \lambda=2 d_{18} \sin \theta_{18} \\
& n \lambda=2 d_{t} \sin \theta_{t} \\
& d_{t}=\mathrm{d}_{1 \mathrm{~s}}(1+a \Delta t) .
\end{aligned}
$$

上の三式ょり

$$
\sin \theta_{18}=(1+\alpha \Delta t) \sin \theta_{c}
$$

從つ

$$
\log \sin \theta_{18}=\log \sin \theta_{t}+\log (1+a \Delta t)
$$$$
t>18^{\circ} \mathrm{C}
$$

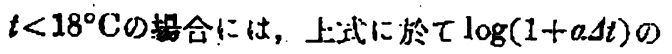

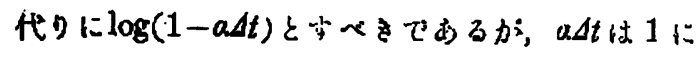
比して甚げ小であるから $-\log (1+a \Delta t)$ としても よいので次式を用ふ。 $\log \sin \theta_{28}=\log \sin \theta_{l}-\log (1+a \Delta t)$

$$
t<18^{\circ} \mathrm{C}
$$

上:式 (49.1), (49.2), (49.3) の何ん加よつて $\iota^{\circ} \mathrm{C}$ に於て唭训した日。より $18^{\circ} \mathrm{C}$ の際とるて

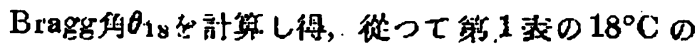

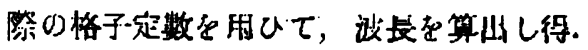

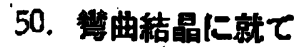

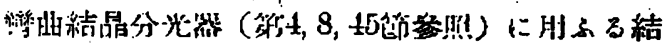

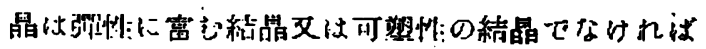
ならぬ. 角者の代裚的なるのは雲目，水晶等で，後

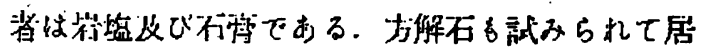

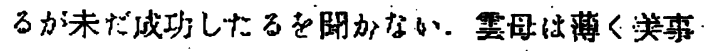

\begin{tabular}{|c|c|c|c|}
\hline i & $a$ & $b$ & $c^{\prime}$ \\
\hline 白雲 & 5.17 & 8.94 & 10.06 \\
\hline 黑 & 5.30 & 9.21 & 10.16 \\
\hline 跂 露 & 5.20 & 8.95 & 10.06 \\
\hline
\end{tabular}

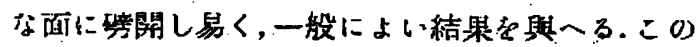

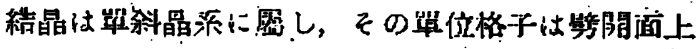
一接 $a$ る

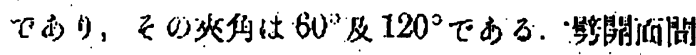

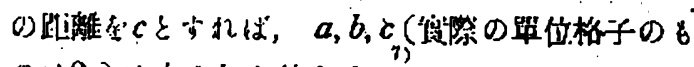

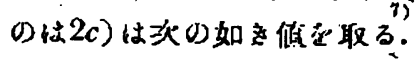

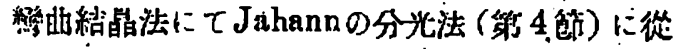

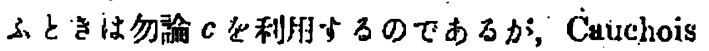
の分光法(第占8節)にては $a$ 在用小。

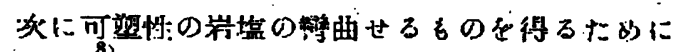

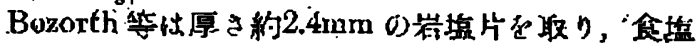
の飽和溶液に浔け七後，指先で数度摖り，凹凹の

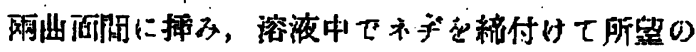
帆率を得な。

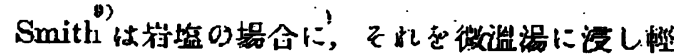
く指先で約 15 秒叞擦し，湯より取出して直ちに所

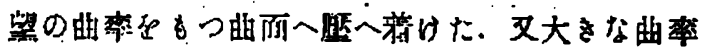

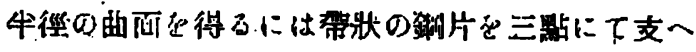
て筬策に得て然る。

7) C. Mauguin: Compt. rend. 1 uิ6 879 (1928)

8) R. M. Bozorth, I. E. Haworth: Phys: Rev. 53 538 (1938)

9) C. S. Smith: Rev. Sci. Instr. 12812 (1041) 
厚さは0.1mmより 0.3nmが缡堂ておう。

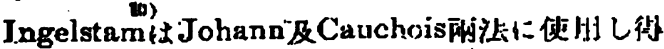

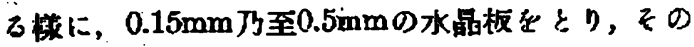

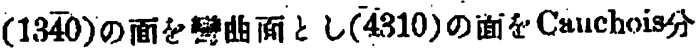

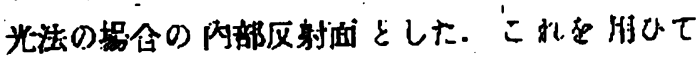

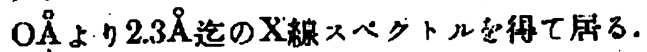

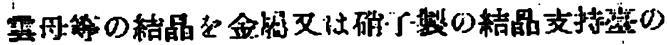

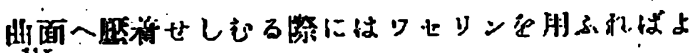
w.

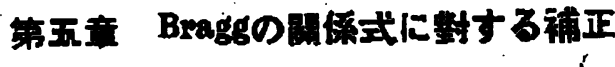

\section{Braggの法則よりの原差}

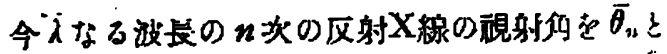
したときBraggの镂係式

$$
n \bar{\lambda}=2 d \sin \bar{\theta}_{n}
$$

快正碓に成立しないことはStenströmによつて, 虾

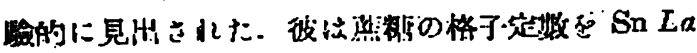

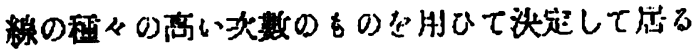

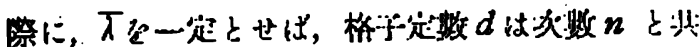

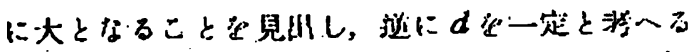

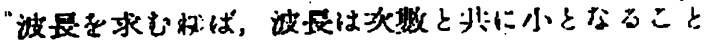

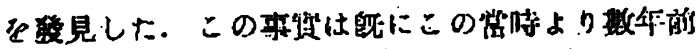
にDarwin及びEwaldにようて弱想されて长た。

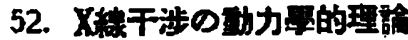

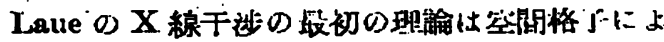

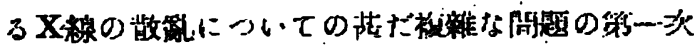

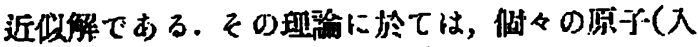

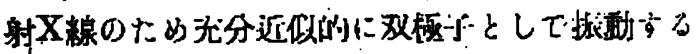

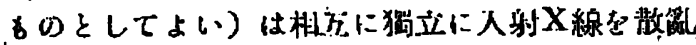

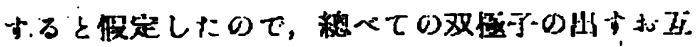

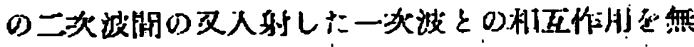

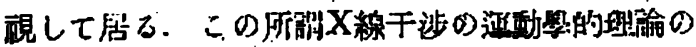

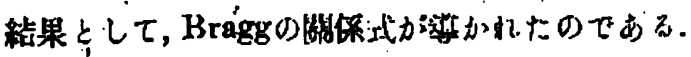

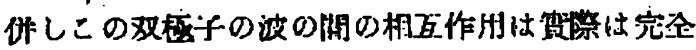

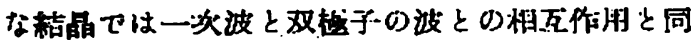

10) E. Ingelstam: Rev. Sci. Instr. 11 160(1940)

11) F. E. Weinstein, D. Bi. Cogrobridge, $M$. N.

- Flerova : J. Exp. Theor. Phys. U.S.S.R. 350 (1940)

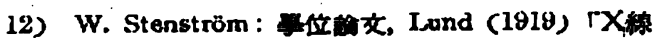

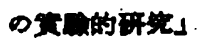

し程发の大さのものである。

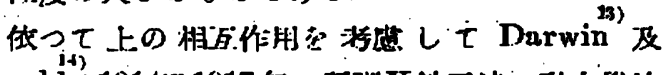
Ewaldは1914及1917年に所腊X綄干涉の预力的

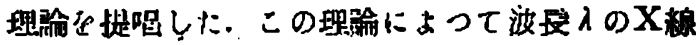

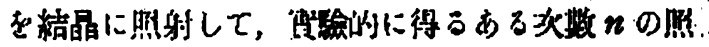

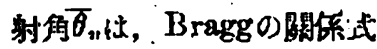

$$
n h=2 d \sin \theta_{n}
$$

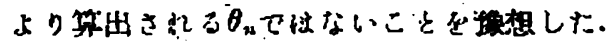

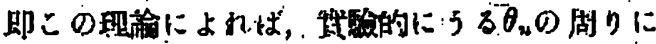

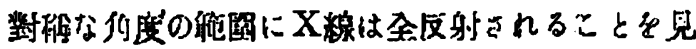
出した。

而して，この全㭱射は望一格ケでは Braggの開

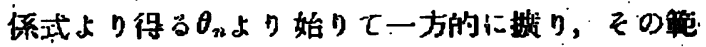
圈は

$$
\Delta \theta_{n}=\sin ^{40} 2 \theta^{\circ}
$$

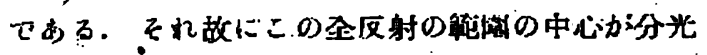
祭的に見州される角度原であるから

$$
\overline{\theta_{n}}=\theta_{n}+\frac{2 \delta}{\sin 2 \theta_{n}} \text {. }
$$

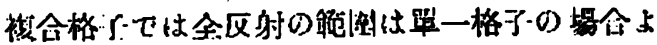

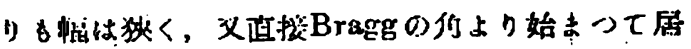

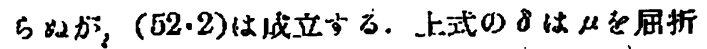

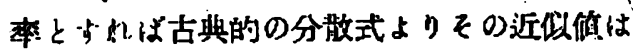

$$
\delta=1-\dot{\mu}=\frac{e^{2}}{2 \pi c^{2} m} \sum_{i} \frac{N_{i}}{\nu^{2}-\nu_{i}}
$$

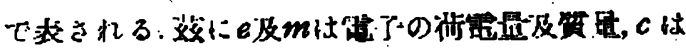

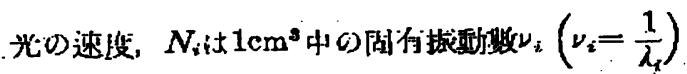

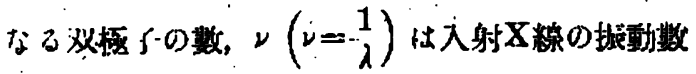

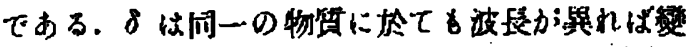

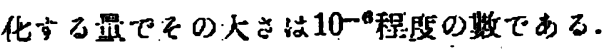

53. Ewald-Darwin の理鍮結果より得万铺正し たBragg式

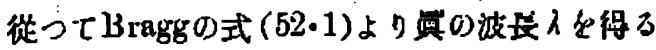

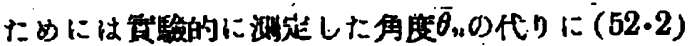

13) C.G. Jarwin: Phil. Mag. $27: 315$; 675 (1914) X新反射の理到

11) P.J'. Ewald; Ann. Physik. 54 514; 577.(191')

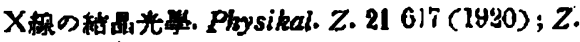
Physik. 2332 (1920); 301 (1924); Phystikal. $Z$. $262 y$ (1925); IIandbuch der Physik. BdXXIV 191 (1927) 
上り得了？

$$
\theta_{n}=\bar{\theta}_{n}-\frac{2 \delta}{\sin 2 \theta_{n}}
$$

を用ひなはればならぬ。

(52.1)に(53.1)の值要代入市儿は

$$
n \lambda d=2 d \sin \left(\bar{\theta}_{n}-\frac{2 \delta}{\sin 2 \theta_{n}}\right)
$$

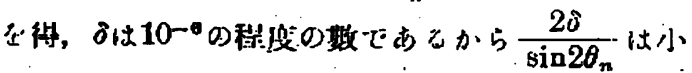

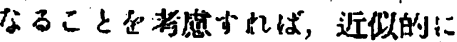

$$
n \lambda=2 d\left(1-\frac{4 d^{3}}{n^{2}} \cdot \frac{\delta}{\lambda^{2}}\right) \sin \bar{\theta}_{3}
$$

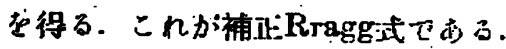

54. Bragg式よリの偏盖を明かたす Ewaldの 缃保式

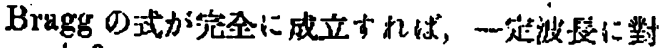

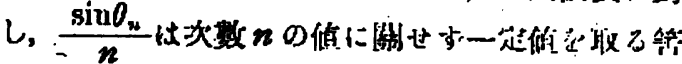

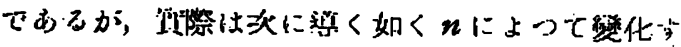
己.

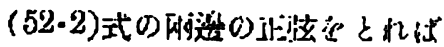

$$
\sin \bar{\theta}_{n}=\sin \left(\theta_{n}+\frac{2 \delta}{\sin 2 a_{n}}\right)
$$

$\frac{28^{\circ}}{\sin 2 \theta_{n}}$ は $\theta_{n} に$ 比し小なる政优であるから, 上式 は近湖的に

$$
\sin \bar{\theta}_{n}=\sin \theta_{n}+\frac{\delta}{\sin \theta_{n}}
$$

、期 $\sin \bar{\theta}_{n}=\sin \theta_{n}\left(1+\frac{\delta}{\sin ^{2} \theta_{n}}\right)$.

(52.1)式より得る $\sin \theta_{n}=-\frac{n \lambda}{2 d}$ 岕上式に代人

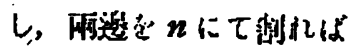

$$
\frac{\sin \overline{0_{21}}}{n}=\frac{\lambda}{2 d}\left(1+\frac{4 d^{2}}{n^{2}} \cdot \frac{\delta}{\lambda^{2}}\right)
$$

网蕧の對数它とれば近似们に

$$
\log \frac{\sin \bar{\theta}_{n}}{n}=\log \frac{\lambda}{2 d}+\frac{4 d^{2}}{n^{\overline{2}}} \cdot \frac{\delta}{\lambda^{8}} .
$$

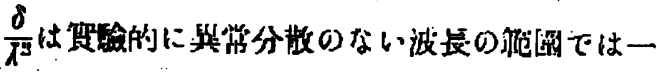
定であるから，A，Bを学数とすれば Ewaldによつ て婑かれた

$$
\log \frac{\sin \dddot{\theta}_{n}}{n}=B+\frac{A}{n^{2}} .
$$

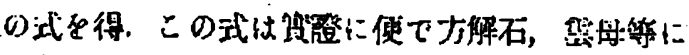

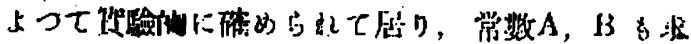
凶的机た。

但しAに含むれる $\frac{\delta}{\lambda^{2}}$ 法簧常分敬の虑即分散する

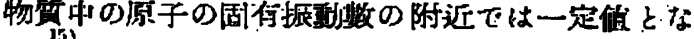
522.

\section{X線の屈折と韨正Bragg式の初的主方}

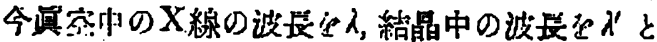

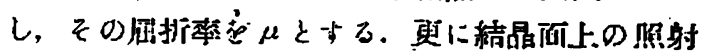

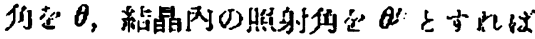

$$
\begin{aligned}
& \mu=1-\delta=\frac{\lambda}{\lambda^{\prime}}=\frac{\cos \theta}{\cos \theta^{\prime \prime}} \\
& n \lambda^{\prime}=2 d \sin \theta^{\prime} .
\end{aligned}
$$

$(55 \cdot 1)$ より

$$
\lambda^{\prime}=\frac{\lambda}{\mu} .
$$

$$
\sin \theta^{\prime}=\sqrt{1-\cos ^{2} \theta^{\prime}}=\sqrt{1-\frac{\cos ^{2} \theta}{\mu^{2}}} .
$$

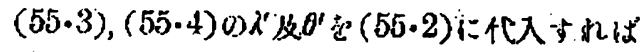

$$
\begin{aligned}
n \lambda & =2 d \sqrt{\mu^{2}-\cos ^{2} \theta} \\
& =2 d \sqrt{1-2 \theta+\hat{o}^{2}-\cos ^{2} \theta} \\
& =2 d \sqrt{\sin ^{2} \overline{\theta-2 \delta+\delta^{2}}}
\end{aligned}
$$

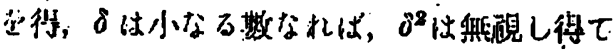

$$
n \lambda=2 d\left(1-\frac{2 \delta}{\sin ^{2} \theta}\right)^{\frac{2}{2}} \sin \theta
$$

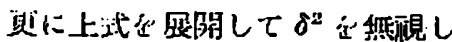

$$
n \lambda=2 d \sin \theta\left(1-\frac{\partial}{\sin ^{2} \theta}\right)
$$

となる。

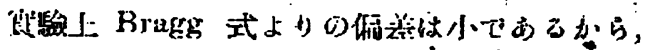
来補琎の Bragg式よりうる $\sin ^{2} \theta=\frac{n^{2} \lambda^{2}}{4 d^{2}}$ ば上试 の拈弧中に入れると

$$
n \lambda=2 d \sin \theta\left(1-\frac{4 d^{2}}{n^{2}} \cdot \frac{\delta}{\lambda^{2}}\right)
$$

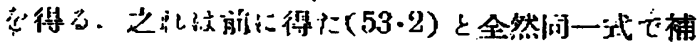
正Bragg式厄むる。

\section{6. 正常分散の範圆に於ける禣正Bragg式，}

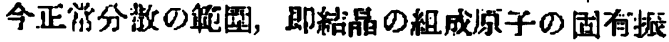

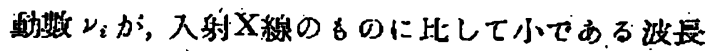
の船洞に於ては，(52.3)式は

$$
\frac{d}{\lambda^{2}}=\frac{e^{2} N}{2 \pi c^{2} m}
$$

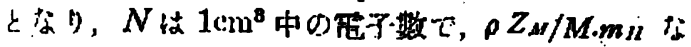

1.5) M. Siegbahn: J. phys. Radium 6298 (1925) 


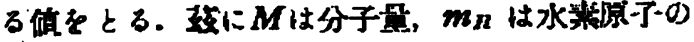

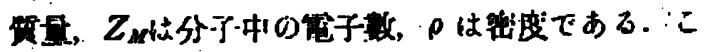

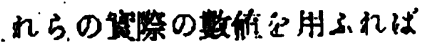

$$
\lambda^{i}=1.36 \times 10^{\circ} \rho
$$

これを，補正Brugg式(55.6)义は(54.1)に代入 サれば

$$
\begin{aligned}
& n \lambda=2 d\left(1-5.40 \cdot \rho \cdot \frac{d^{2}}{n^{2}} \cdot 10^{-6}\right) \sin \theta(56 \cdot 3) \\
& \text { 今 } \alpha_{n}=d\left(1-5.40 \cdot \rho \cdot \frac{d^{2}}{n^{2}} \cdot 10^{-0}\right) \quad(56 \cdot 4)
\end{aligned}
$$

とおけけば，補」FBragg式は Bragg式と全く闹形の 式

$$
n \lambda=2 d_{n} \sin \theta
$$

となる。

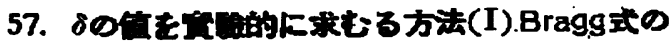

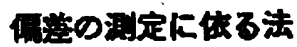

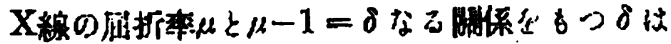

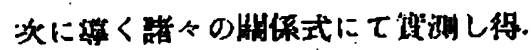

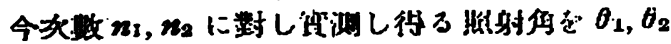
とナれば，(55.5)式に夫゙の做代入して得る二

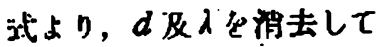

$$
\delta=\frac{\sin \theta_{1} \sin \theta_{2}\left(n_{2} \sin \theta_{1}-n_{1} \sin \theta_{2}\right)}{n_{2} \sin \theta_{2}-n_{1} \sin \theta_{1}}
$$

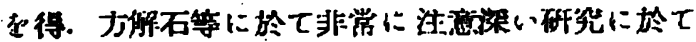

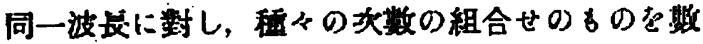

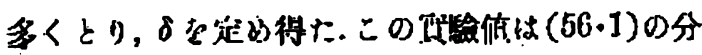
散式よりの訃算值とょく一教した。

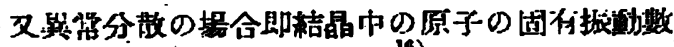
に近い附近を初めて Siegbahn筞によつて (57.1)

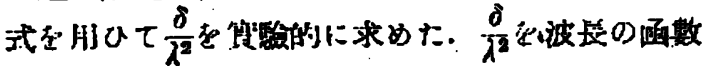
としてあらはせば，非常に被雜でこ可舆常は結 晶中のCa及S源于に蹛せられた。この所でるの值 はその近伤よりす小さな㑬ととる。

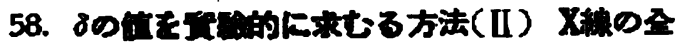
反射

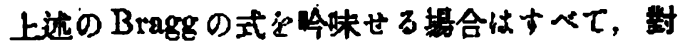

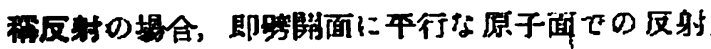

16) - M. Sieghahp, E. Hjalmar, Nature 11585 (1925); M. Siegbahn, J. phys. Radium 62288 (1025); K. Hjolmax, Ann Physik. (4) 79550 (19226) (石青).

\section{起教察した。}

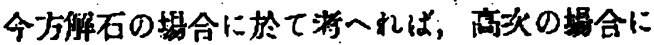
は低次の反射角より見出される6のよりも約3”の

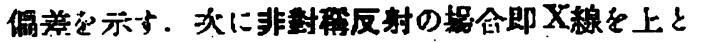

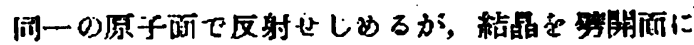

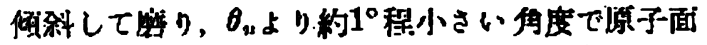

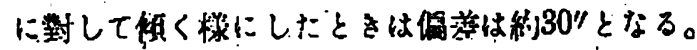

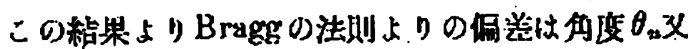

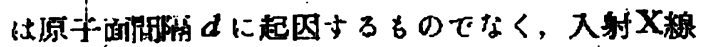
と結唱非亩との解度によることか明白である。こ

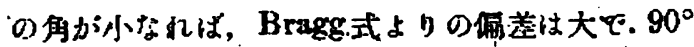

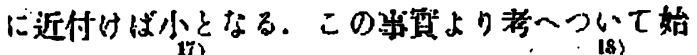
めて Comptonによつて，叉その後 Sieghahnによ つて，約数分の小さな能度で結晶面（銀，石亩等）

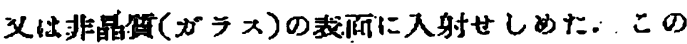

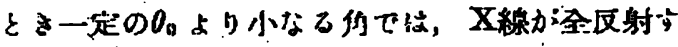
ること惩めた。

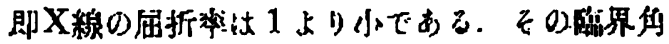

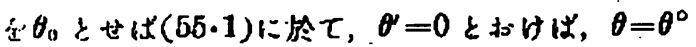

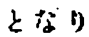

$$
\cos \theta_{0}=\mu \quad \text { य位 } \sin \theta_{0}=V 2 \delta
$$

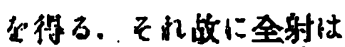

$$
\cos \theta>\mu \text { 文は } \sin \theta<\sqrt{2 \delta}
$$

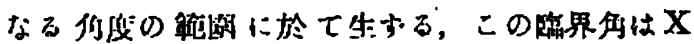

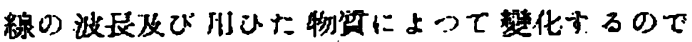

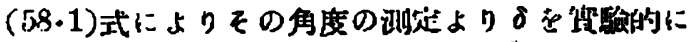
测定し得る.

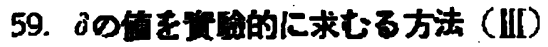
プリスムによるX線の届折

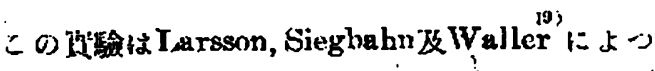

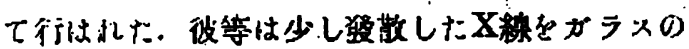

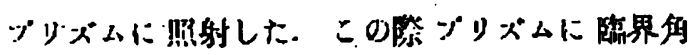
的より小なる何度で祭射ちるるのは全反射し，飞

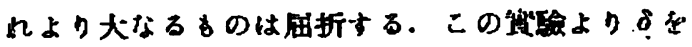

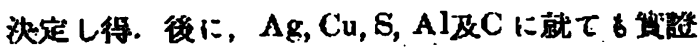
した.

\section{0. 正Brage式の吟味}

17) A. H. Complon: Phil. Mag. is 1121 (1923)

18) M. Sieguahn: Fysisk, Tidsskr. \&1 170 (1923)

19) A. Larisson, M. Sieglahn, J. Waller: Naturwisisenschaften 12.1212 (1921) 


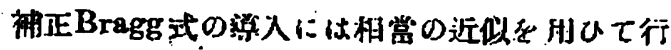
こからこの式の精陮さ吟味するために，Cu

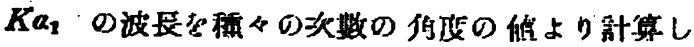
た.このと、の解度は算湖做ではなく，(54,2)式 爻州ひたるのである。即この揭合に治

$$
\log \frac{\sin \theta_{n}}{n}=8.8883085+0.0006798 \cdot n^{-2}
$$

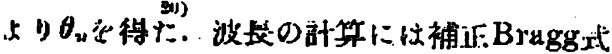

$$
n \dot{\lambda}=19.88104\left[1-\frac{0.001565}{n^{2}}\right] \sin \theta_{n}
$$

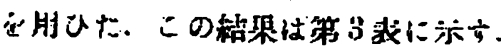

\begin{tabular}{|c|c|c|}
\hline 头 数 & 㭪正せるるの & 㭪正せざるるの \\
\hline 1 & $15: 97.260 \times$ 品位 & $1537.260 \times$ 望位 \\
\hline 2 & 1537.261 & 19i:5.457 \\
\hline$: \because$ & 1537.261 & 7.535 .123 \\
\hline 4 & $15: 37.361$ & $15: 35.106$ \\
\hline 5 & 1537.261 . & $1031.95: ?$ \\
\hline G & 1537.261. & 1534.922 \\
\hline 7 & 1537.262 & 1534.905 \\
\hline 8 & 1537.262 & 1534.803 . \\
\hline ) & 1537,262 & 1534.885 \\
\hline 10 & $10: 37.262$ & 1531.880 \\
\hline
\end{tabular}

第 3 表

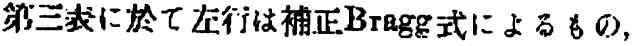

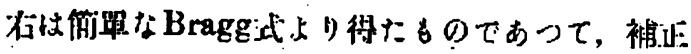

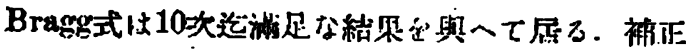

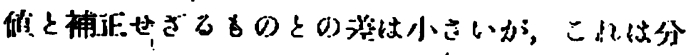

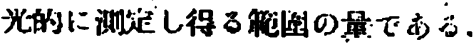

\section{1. 浦正Bragg式に佉る波長の针算}

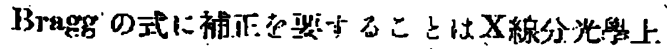

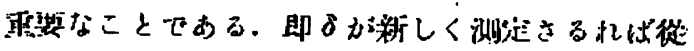

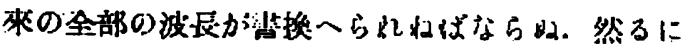
睡に多くの波長は测定されて居る。この速影を避

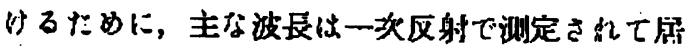

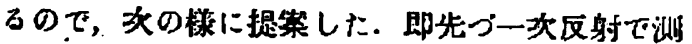
定した绦は方解石では $d=3.029040 \AA$ ，岩嚓ては $d$

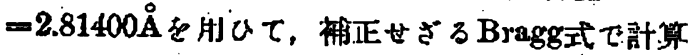

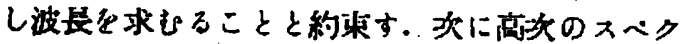

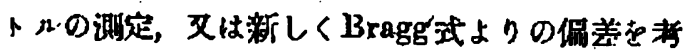

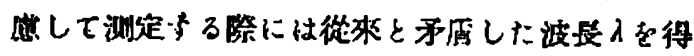

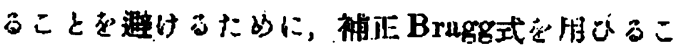

20) A. Larsison: Z. Physik 35401 (1026)
ととした. 但その際衼正Bragg式(53.2)(55.6)に 於て, $d$ としは $d=\lim d_{n}$ 啋用しなけんばな ら叹。の僄は

$$
d_{n}=d\left(1-\frac{4 d^{2}}{n^{3}} \frac{\delta}{\lambda^{2}}\right)
$$

$に \tau n=1 と し \tau$

$$
d x=d\left(1-4 d^{2} \frac{\delta}{\lambda^{2}}\right)
$$

期近似的に

$$
\text { - } d=d_{1}\left(1+4 d^{3} \frac{\partial}{\lambda^{2}}\right)
$$

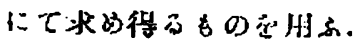

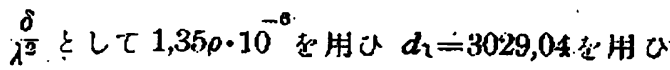

$$
\text { c. } d=\operatorname{Tin}_{n \rightarrow \infty} d_{n 2}=3029.45 \times \text { 华位. }
$$

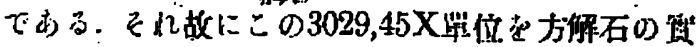

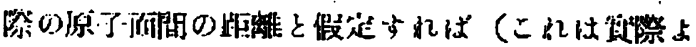
ク少し大なる倾でるが吾かは一次の反射を取

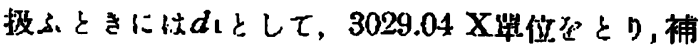
政せざる Bragg式

$$
\lambda=2 d_{1} \sin \dot{\theta}
$$

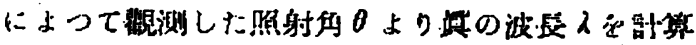

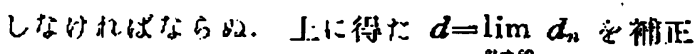

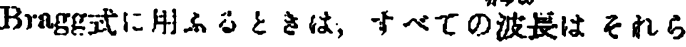

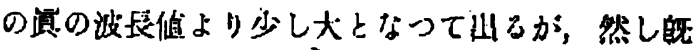
に苦より得られて郎る僻に一致し，第三表にて明 かな如く、メハクトル線の次數に無攵係となる。

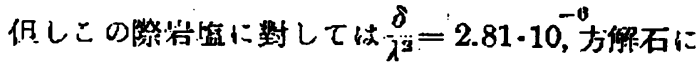

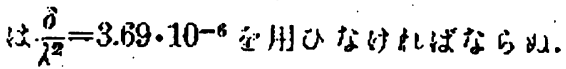

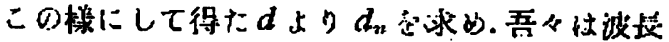

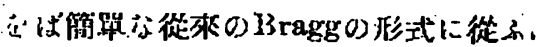

$$
n \lambda=2 d_{n} \sin \theta_{n} \text { 、 }
$$

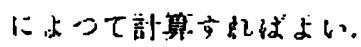

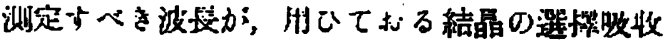

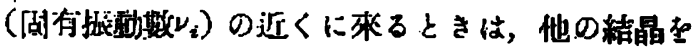

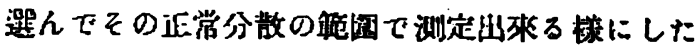
オがい.

\section{2. 神正Bragg式の例}

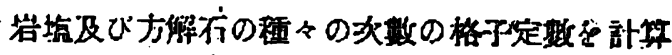

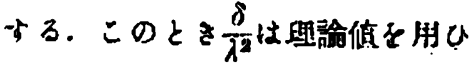

$$
n \lambda=2 d\left(1-\frac{89}{n^{2}} \cdot 10^{-6}\right) \sin \theta
$$

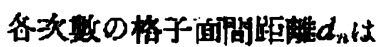




$$
\begin{aligned}
& d_{1}=2814.000 \times \text { 筆位 } \\
& d_{2}=2814.188 \\
& d_{8}=2814.222
\end{aligned}
$$

$\lim \mathrm{d}=d=2814,222$

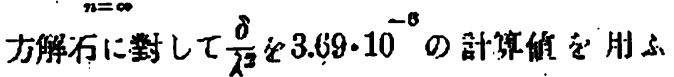
n洋

$$
\begin{aligned}
& n \lambda=2 d\left(1-135 \cdot 10^{-8}\right) \sin \theta_{n} \\
& d_{1}=3029.040 \quad \text { X帮位 } \\
& d_{2}=3029.34 \\
& d_{s}=3029.40 \\
& d_{4}=3029.42 \\
& d_{5}=3029.43
\end{aligned}
$$

$\lim d_{n}=d=3029.45$

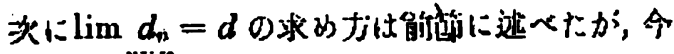

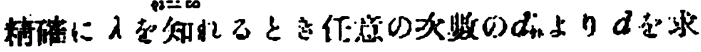

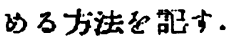

$$
d_{n}=d\left(i-\frac{4 d^{2}}{n^{2}}-\frac{\delta}{\lambda^{2}}\right) \cdot
$$

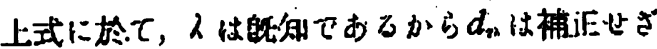

るBraggの式より求历る。それ故に

在補正倠として

$$
d=d_{n}+x
$$

とおけば，xの值を求しれげ所望のdの值を求め 得べし.

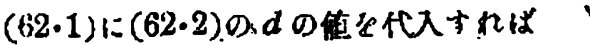

$$
\begin{aligned}
& d_{n}=\left(d_{n}+x\right)\left[1-\frac{4}{n^{2}} \cdot \frac{\delta}{\lambda^{2}}\left(d_{n}+x\right)^{2}\right]= \\
& d_{n}+x-\frac{4}{n^{2}} \frac{\delta}{\lambda^{5}}\left(d_{n}+x\right)^{2} .
\end{aligned}
$$

\begin{tabular}{|c|c|c|c|c|c|c|c|}
\hline & & 榑 & Bro & 式 & 洞 笌 & 梢 正 红 & \\
\hline & 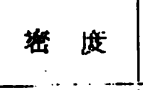 & $\frac{\delta}{\lambda^{*}}$ & $d_{1}$ & $d_{n}$ & 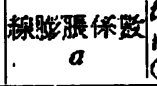 & 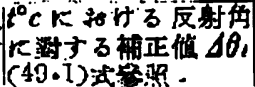 & 交 \\
\hline 岩 㹕 & & $281.10^{-0}$ & $281.4(x)$ & $2814.25\left(1-\frac{89}{n^{*}} \cdot 10^{-6}\right)$ & $4.04 \times 10^{-5}$ & 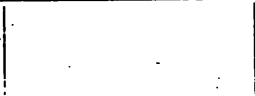 & 2) \\
\hline 方解石 & $\begin{array}{l}2.7102 \\
\left(20^{\circ} \mathrm{c}\right)\end{array}$ & $\begin{array}{c}3.69 \% 100^{-14} \\
-\end{array}$ & 3029.04 & $3029.40\left(1-\frac{125}{n^{2}} \cdot 10^{-0}\right)$ & $1.0^{2} \times 10^{-8}$ & $2 \ln \left(t-18^{\circ}\right) \tan \theta$ & 2) \\
\hline 水 最 & 2.65 & $3.60 \cdot 10^{-0}$ & 4914.\$2 & $4216.02\left(1-\frac{259}{x^{3}} \cdot 10^{-6}\right)$ & $1.04 \times 10^{-5}$ & $2.15\left(t-18^{\circ}\right) \tan \theta$ & 1) \\
\hline 石， 尚 & 2.32 & $3.23 \cdot 10^{-8}$ & $7579-07$ & $7584.70 .\left(1-\frac{742}{n^{2}} \cdot 10^{-0}\right)$ & $3.78 \times 10^{-5}$ & $7.7 \forall\left(t-18^{\circ}\right) \tan 0$ & 4) \\
\hline 露 冓 & & $3.86 \cdot 10^{-8}$ & 9927.58 & $90 \cdot 12.72\left(1-\frac{1522}{n^{2}} \cdot 10^{-6}\right)$ & $1.53 \times 10^{-6}$ & $3.16\left(t-18^{\circ}\right) \tan 0$ & 3) \\
\hline & $\begin{array}{c}(2.8-3.2) \\
4 \times 3.3\end{array}$ & $4.06 \cdot 10^{-0}$ & 9925.0 & $9910.52\left(1-\frac{1565}{x^{2}} \cdot 10^{-8}\right)$ & & & 2) \\
\hline
\end{tabular}

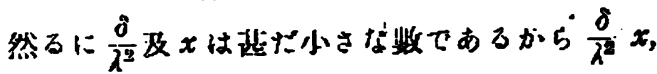

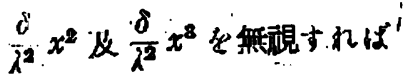

$$
x=\frac{4}{n^{2}} \frac{\delta}{\lambda^{2}} d_{n}^{8} \text {. }
$$

從った

$$
d=d_{2}\left(1+\frac{4 n_{2}^{3}}{n^{2}} \cdot \frac{\delta}{\lambda^{2}}\right),
$$

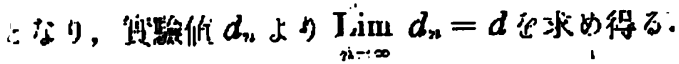

\section{X線分光机用ふ万結晶の㭪正Bragg式}

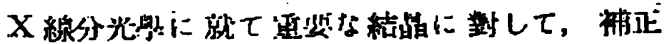

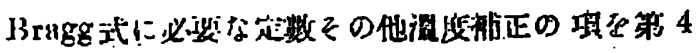
措に禁歺。

第 4 辣

1) O. Bergquist : Z. Physik 66 494. (1930)

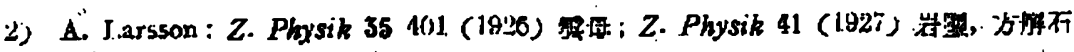

3) M. Siegbahn: "Spektroskopie dey Röntgenstrahlen" 第二服 4 (1931)

4) S. v. Friesen : Z. Physik 64679 (1924) 


\begin{tabular}{|c|c|c|}
\hline shiless & \multicolumn{2}{|r|}{ 潭田: $\mathbf{X}$} \\
\hline 64. 波長の僄新 & & * \\
\hline 取与精確に测穴 & されたX㳏スべ & クトル被は \\
\hline$F c K a_{2}$ & $1932.076 \times$ 䇴信 & \\
\hline $\mathrm{Cu} K a_{3}$ & 1537.396 & $\because$ \\
\hline _ Mo $K a_{1}$ & 707.831. & \\
\hline
\end{tabular}

\begin{tabular}{|c|c|c|c|c|}
\hline \multicolumn{3}{|c|}{ Al $K a_{1,2} 8322.48 \mathrm{X}$ - 紧位 } & Se $K a_{1}$ & 1102.48 \\
\hline $\mathrm{Nb} K a_{1}$ & 744.65 & & $\operatorname{Cr} K o_{1}$ & 2285.03 \\
\hline $13 r K\left(a_{1}\right.$ & 1037.59 & & $R u K a_{1}$ & 641.74 \\
\hline $\operatorname{Mn} K a_{1}$ & 2097.51 & & $\mathrm{Rlb} K a_{1}$ & 923.64 \\
\hline$R u K a$ & 612.02 & & Co $K a_{1}$ & 1785.29 \\
\hline Sr $K a_{1}$ & 873445 & & $\mathrm{Pd} K a_{1}$ & 584.27 \\
\hline Ni $K a_{1}$ & 1654.50 & & $Y K a_{1}$ & 827.12 \\
\hline Ag $K a_{1}$ & 558.28 & & As $K a_{1}$ & 1173.44 \\
\hline$/ / s K a_{1}$ & 784.30 & & Sn $K a_{1}$ & 489.57 \\
\hline
\end{tabular}

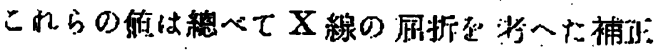

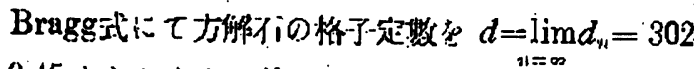
9.45 としたとす的である.從來股す正しいと将

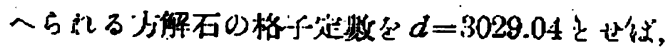

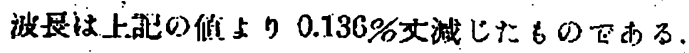

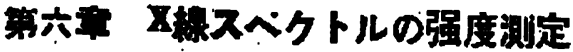

\section{5. 緒}

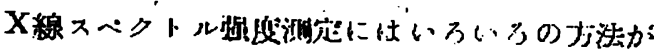
あ己.

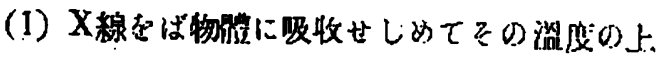
景支利用与るるの，及好

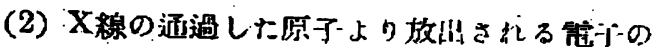

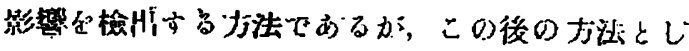
$\tau$ 蛙

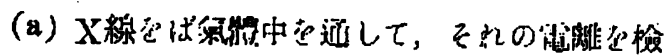

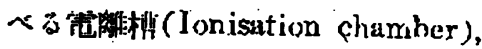

(b) 光代门及び反报胡子- (Recoil clectoron) か;

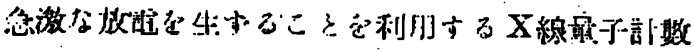
器(Counter; Zähler)等在利䏳儿, 又

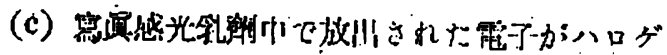

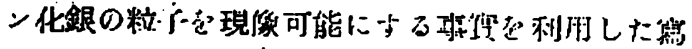

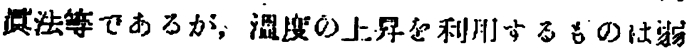
いX線に對して，殊にスべクトル線の柡な細く塽

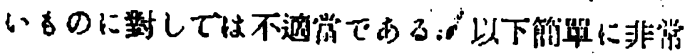

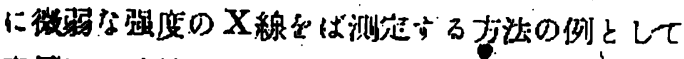

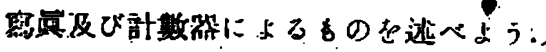

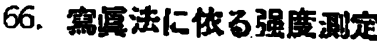

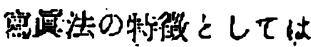

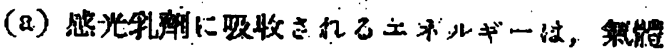

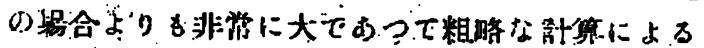

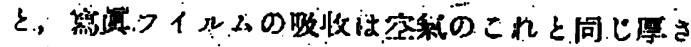

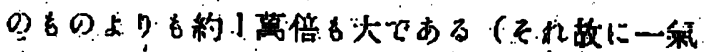

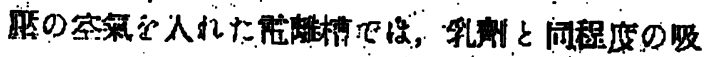

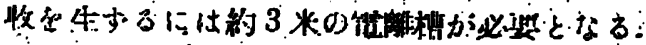

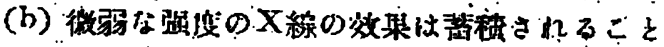

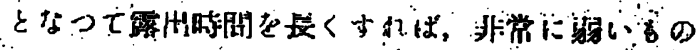
で旅出しうる。

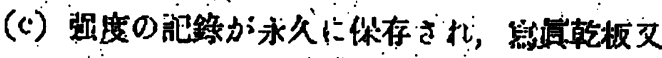

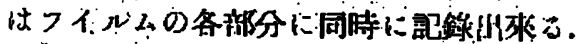

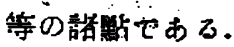

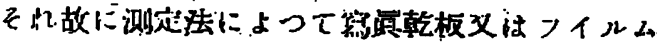

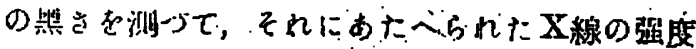

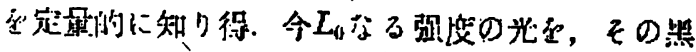

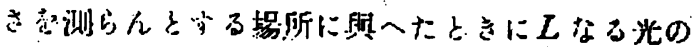
雷大け透泪したとすると

$$
S=\log _{10} \frac{L_{0}}{L_{i}}
$$

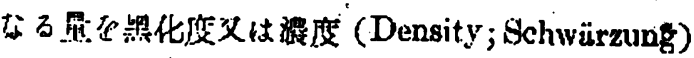
と云ふ.

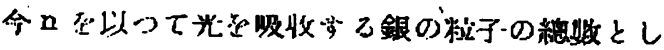

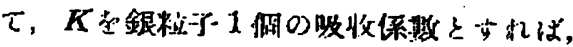

$$
L_{1}=L_{1} e^{-11 k}
$$

となり ととなる.

この㥞にして，光度計で测つた黑化度は照射し たX線の他に，察琪乾板の稙颣，現俰の時間，溫

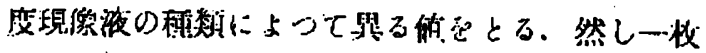

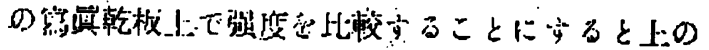

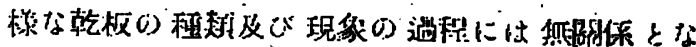

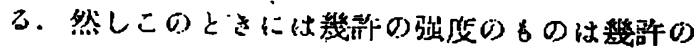

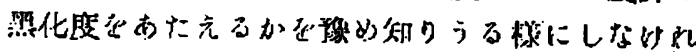
ばならる。

\section{これには}

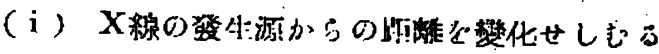
加

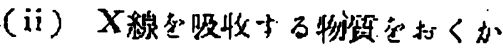

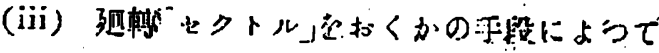

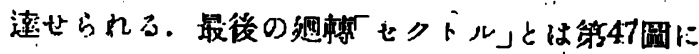

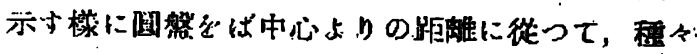




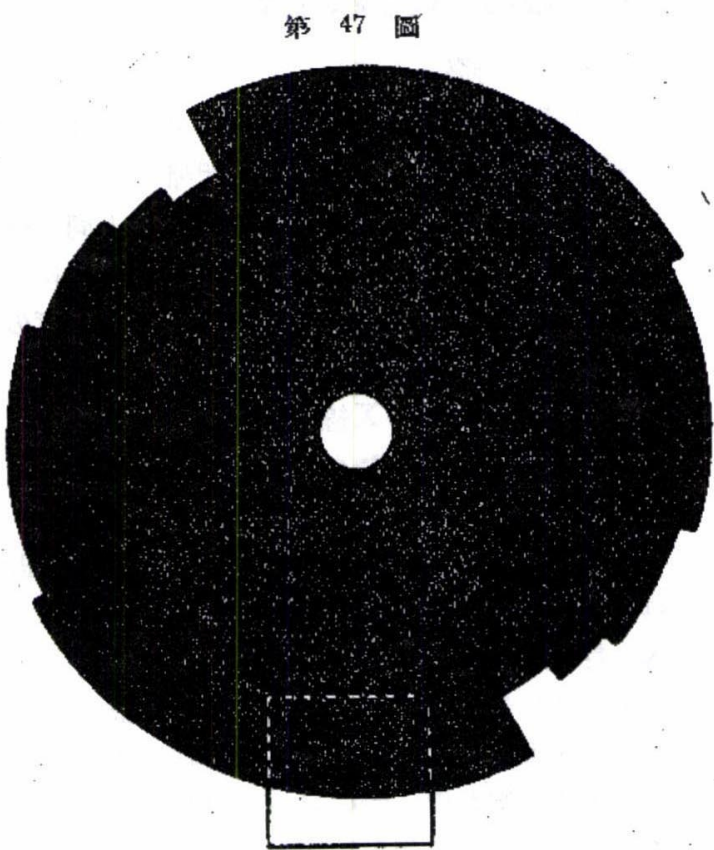

の制合で切取つているので，この山盤至X線の通

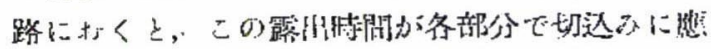

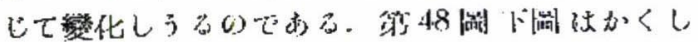

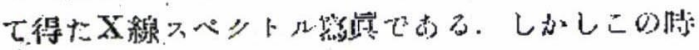

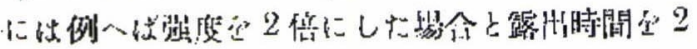

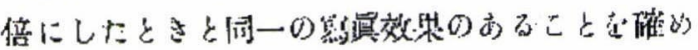

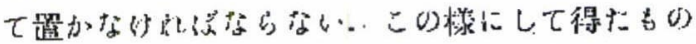

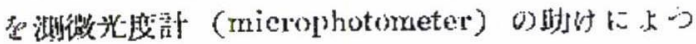

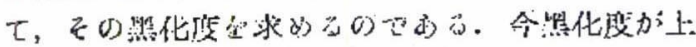
の栐にして現像の過程によらないものとなったか

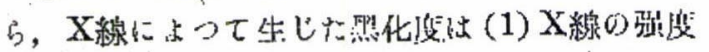

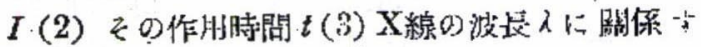
るものであって, 一般に

$$
S=f \cdot(I, t, \lambda)
$$

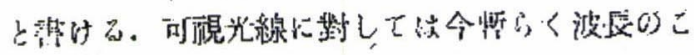

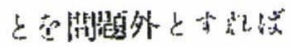

$$
S=f \cdot\left(I \cdot t^{\prime \prime}\right)
$$

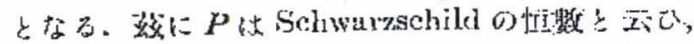

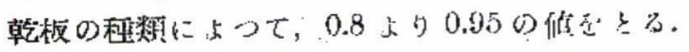

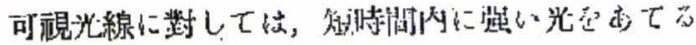

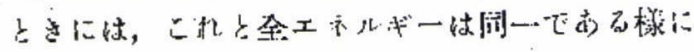

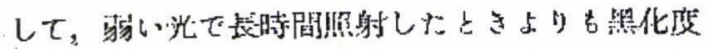

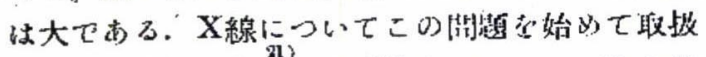

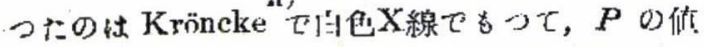

21) Kröncke : Dissertation Göttingen (1913) Ann. phvsik 43687 (1914)
颌 18 圆
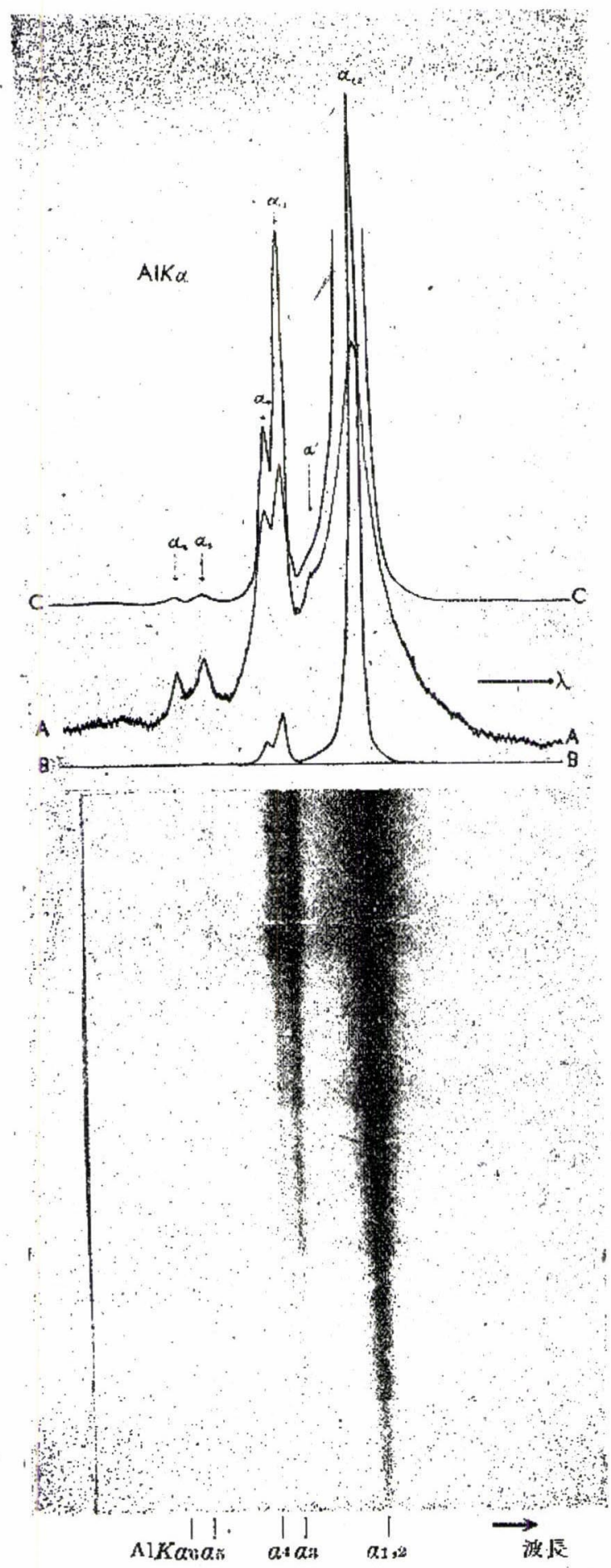

は0.96より 1 の咸の的志とるとした。

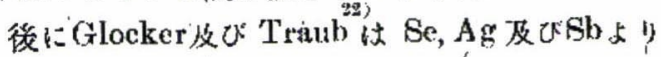

22) R. (Xlocker, W. Traub; Physikal. Z. 22351 (1914) 
の片示性 X 榞ては $P$ の平均做として $P=0.98 \pm$ 0.01 得た. Bouwers は 1 に近しがこれょり.す

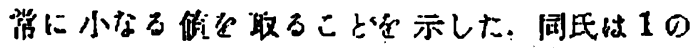

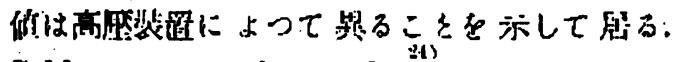

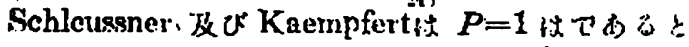
して居る.P=1をすると然化度はItに俄ることを

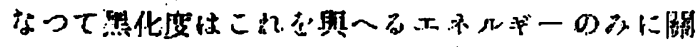

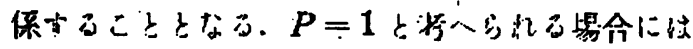

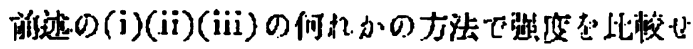

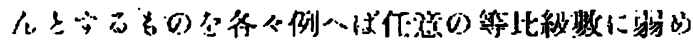

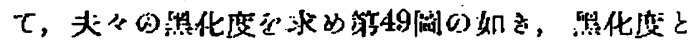

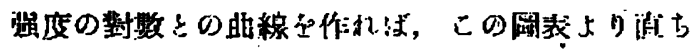

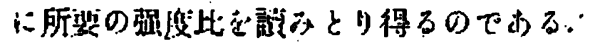

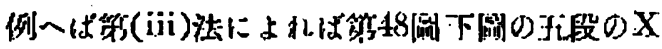

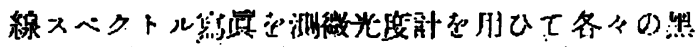

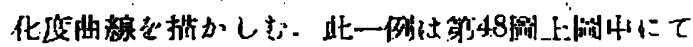

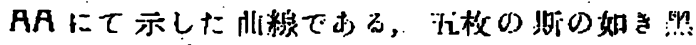

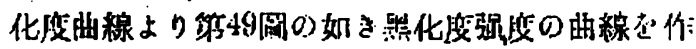

蚂 49 率

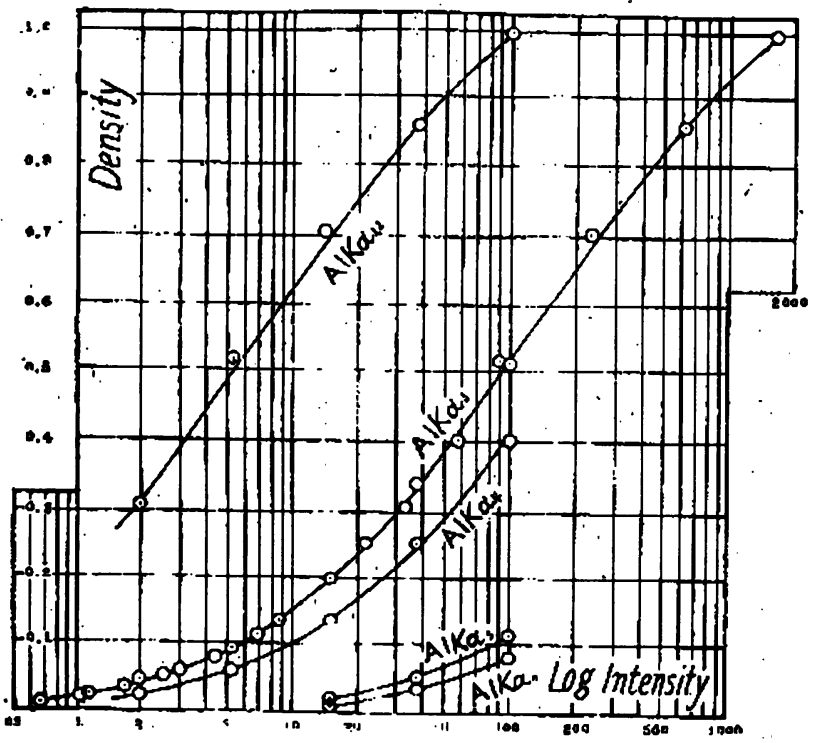

上沪连心た䢕では波長に就いて将人て居らなか つたが，同一の゙ラネルギーのすのです波長が異な

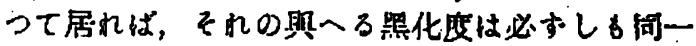
ではないので，强度色隶めるとるにこの點居将虑

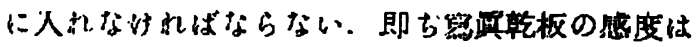

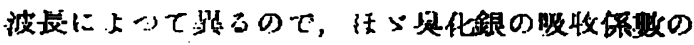

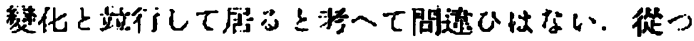

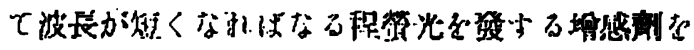

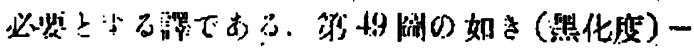

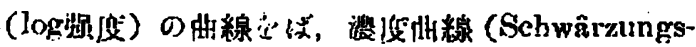

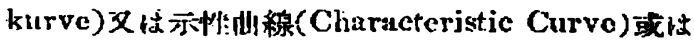

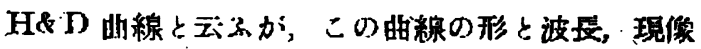

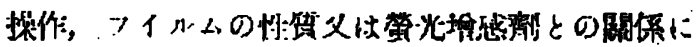

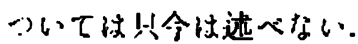

\section{X線量子計数器}

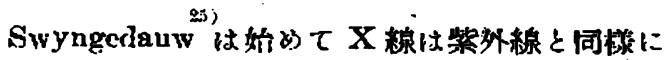

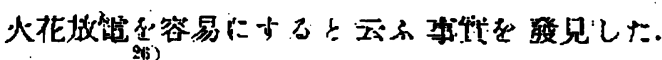

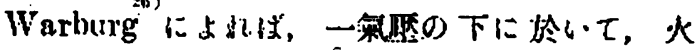

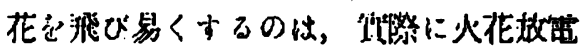
代必装な部压る下りるのではなくて火花

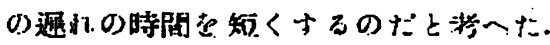

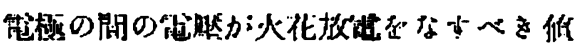

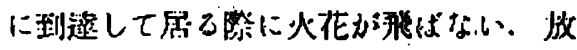

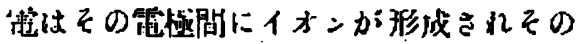

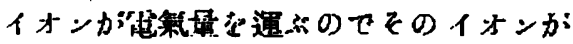

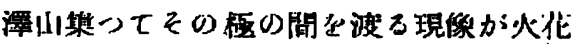
放彗であうて，高電压になつたときその 極の近くで放䉓に充分なイオンの数を作 るために姴する時間が火花放電の時間で ある: 從つて電極に火花放電に然分な電 恹がかる前にX線棸仙紫外線でイオン

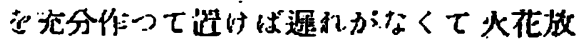
㨁が行行古る笋である。

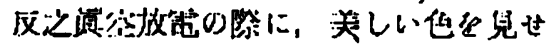

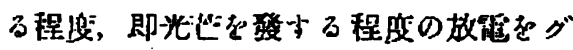

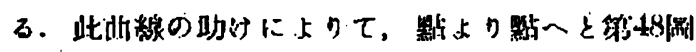

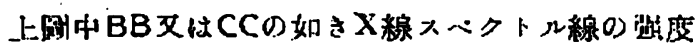

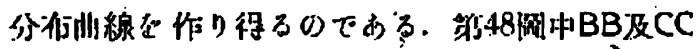

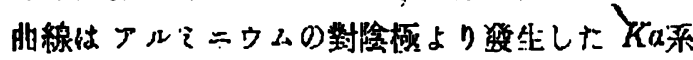
列のスヘクトル線の强经分布である。

23) A. Bouwers: Dissertation Utrecht (1924)

24) C.A. Schleussner, W. Krempf(rt : Fortschr. a. d. geb: d. Rz̈ntgenstr 32593 (1924)

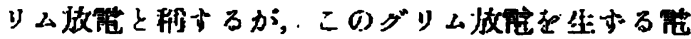

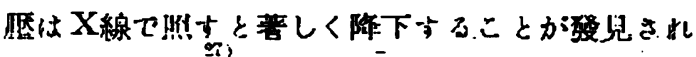

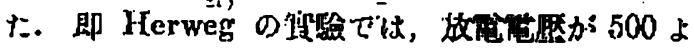
ク 600 ヴォルトのとをに，X線で然与と10ヴォル

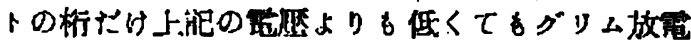

25) R. Swyngedauw : Compt. rend. 122374 (1896)

26) E. Wärburg: Anse phys. 5811 (1901)

37) J. Herweg: Ann. phys. 19330 (1906) 


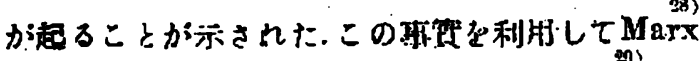

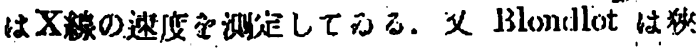

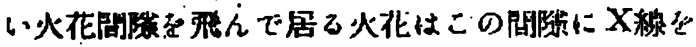

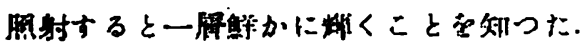

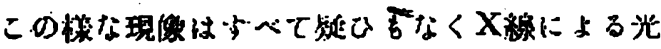

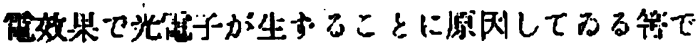

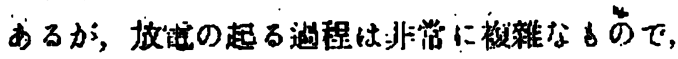

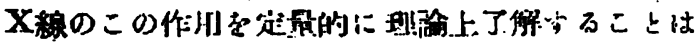
因隺なことである。

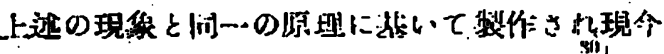

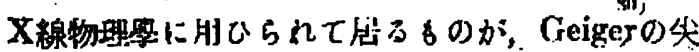
端言十数器(Spitzonzähler)である。

これは元來は. Rutherfolel 及び (ieiger 阿块か;

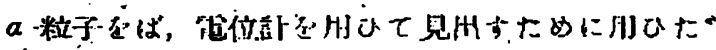
装得である。

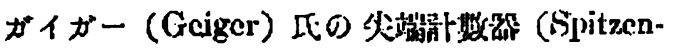

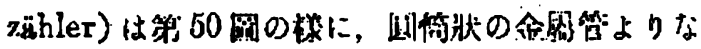

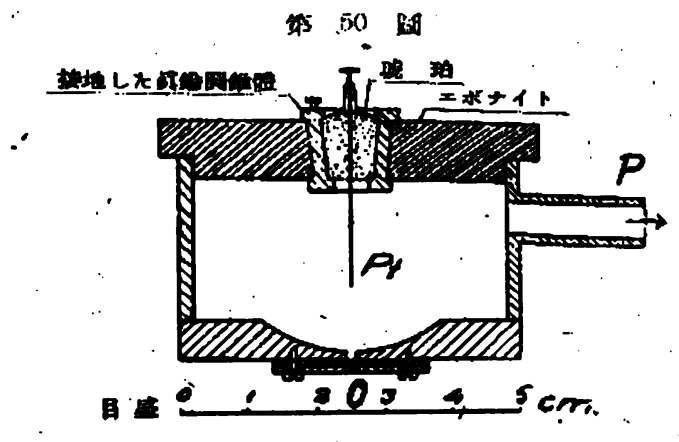

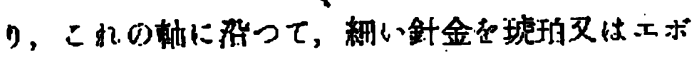
ナ゙イトで絶して道いてある。これなPより真察 ボンプにて約 2 雬及は 3 䊔程度に排策して，この

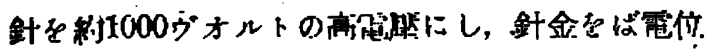

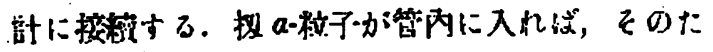

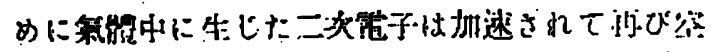

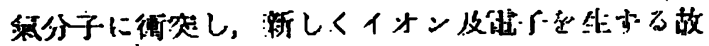

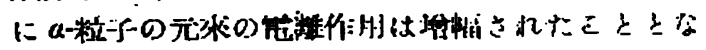

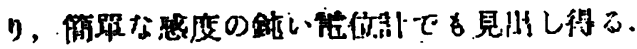

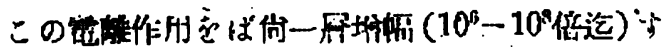
るたるには Geiger 氏汹針金の做栖の代りに，尖

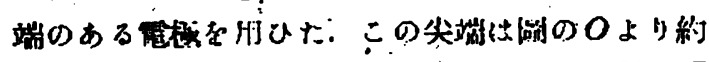

(i8) E. Marx: Verb. d:D. Phys. Ges. 10 628(1308)

20) R. Blundlut : Comp. rend. 1341559 (1002)

30) H. (ieiger: Verh. d. D. Phs. Ges. 15534 (1913)

31) E. Rutherfold. It. Geiger.: Proc. Roy. Soc. London 81141 (1308)

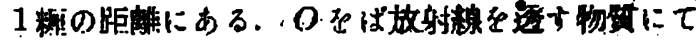

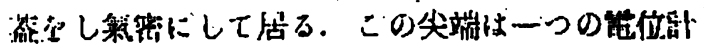

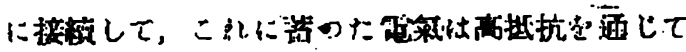
接地さ虬て处公。

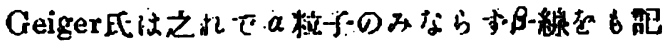

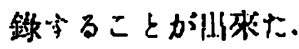

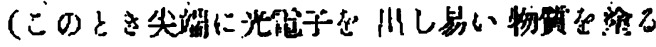

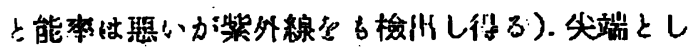

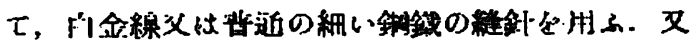

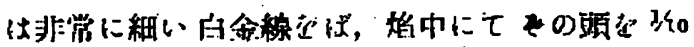

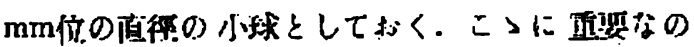

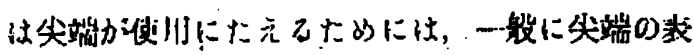

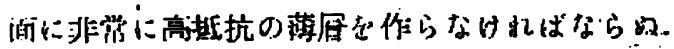

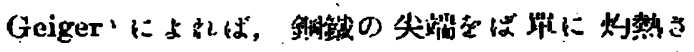

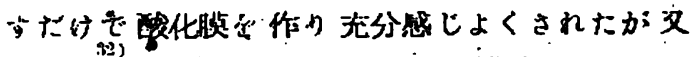

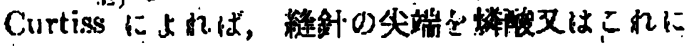

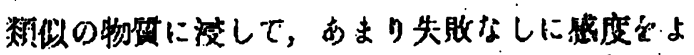

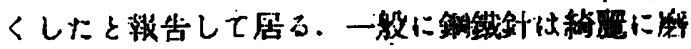

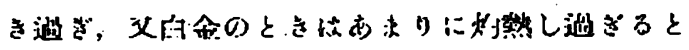

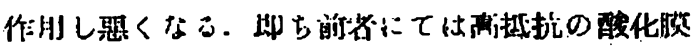

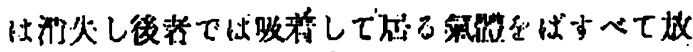

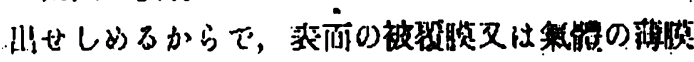

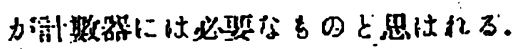

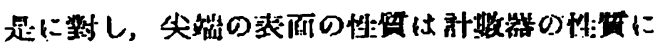

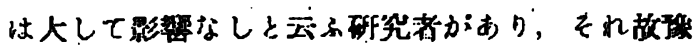

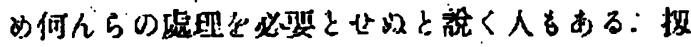

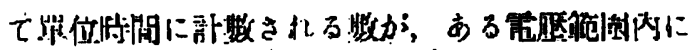

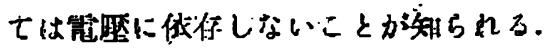

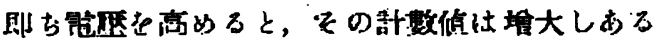

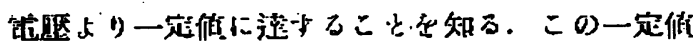

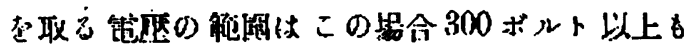

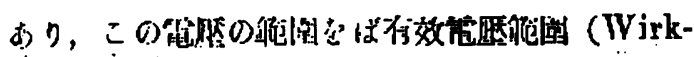
sam Spannungsibercich) と五ふ.上の新敗器は

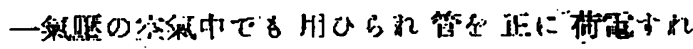

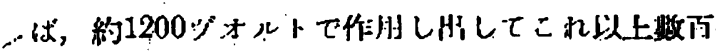

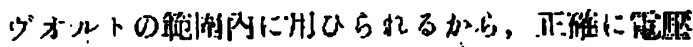

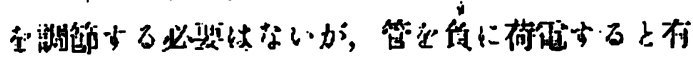

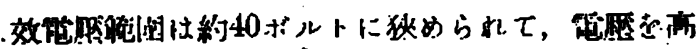

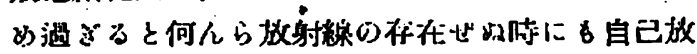

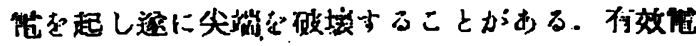

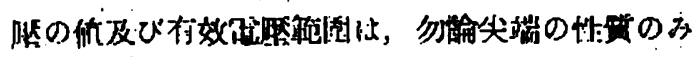

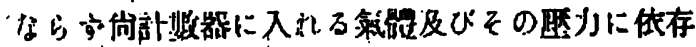

32) L.F. Curtiss: Physs. Rew 31302 (i928) 
して居る。

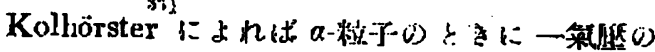
下の然策では 3350-1750 水ルト，闹じく水瑟の

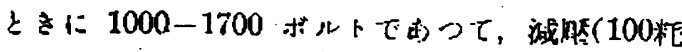

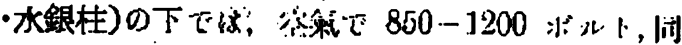

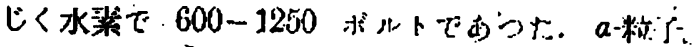

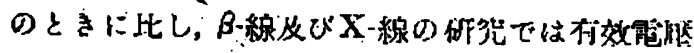

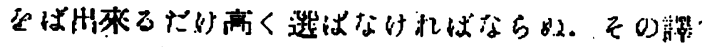

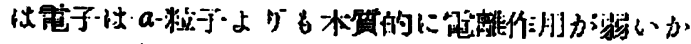

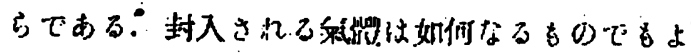

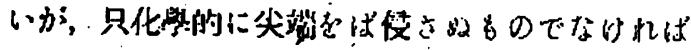

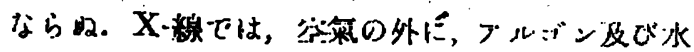

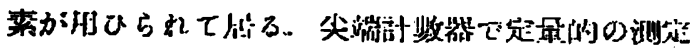

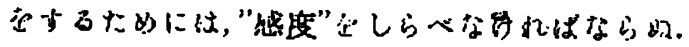

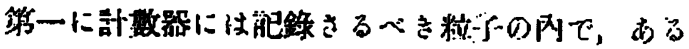

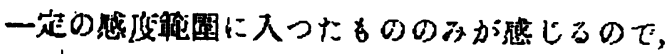

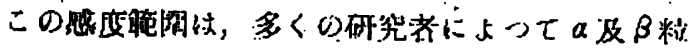

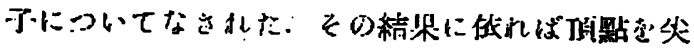

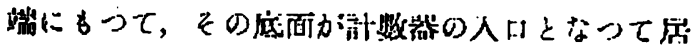

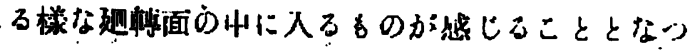

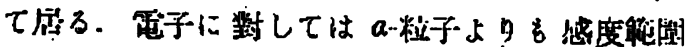

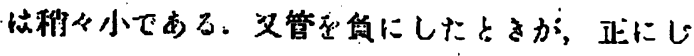

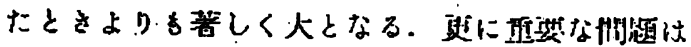

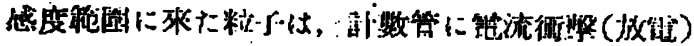
を興へるかどうかである。

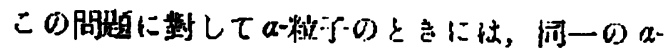

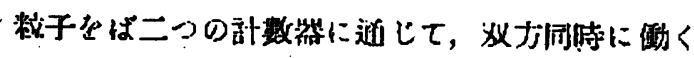

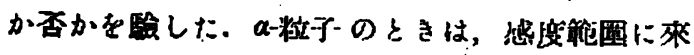

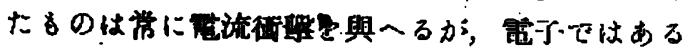

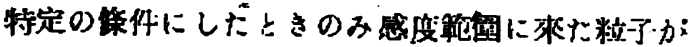

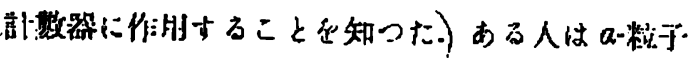

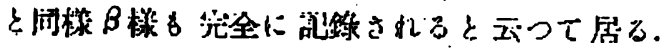

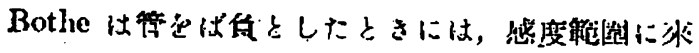

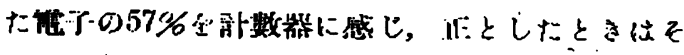

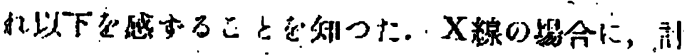

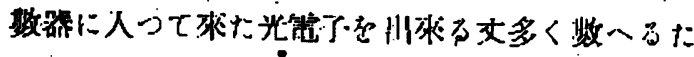

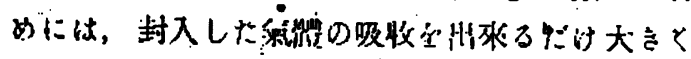

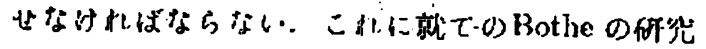

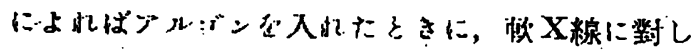

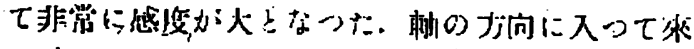

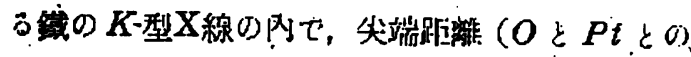

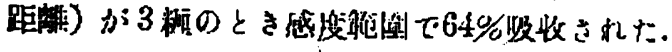

33) W. Kòlhörster. Z. Physik. 2257 (1920)

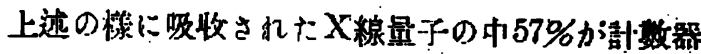

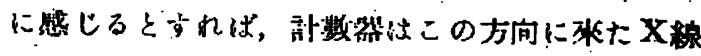

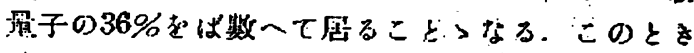

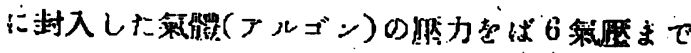
ト利せしめても别に得ることはながた。何故な

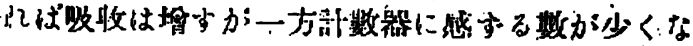
るからである。

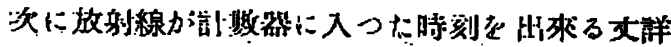

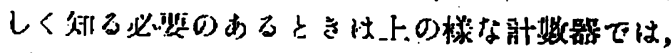

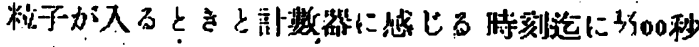

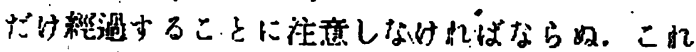

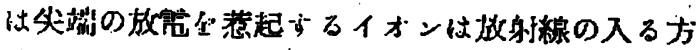
向によつて，尖端よりそれぞれ算つけ距堆で生し るからである。そ机故にイオンか尖端人近朴く前

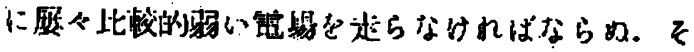

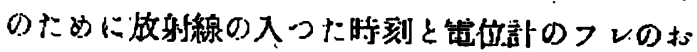

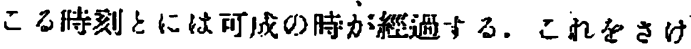
むために，Bothe及Geiger は尖端の後すへ一っの

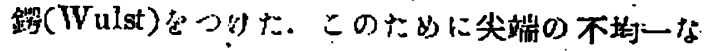

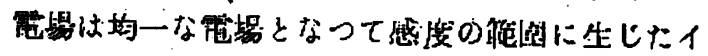
オンは一䚄速く尖端に引引けられることつなつ

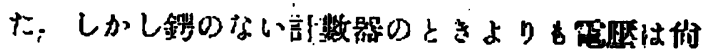

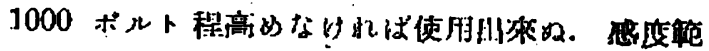

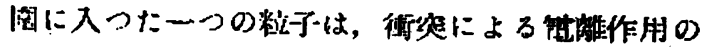

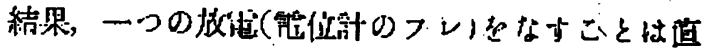

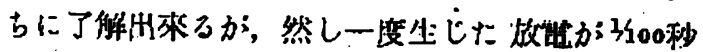

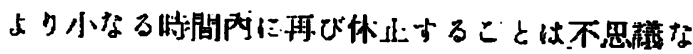
事であるこれについていろいろの說明があるか 一說には尔端の洨被を被つて居る比䡈的大きな坻

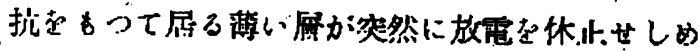

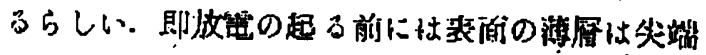

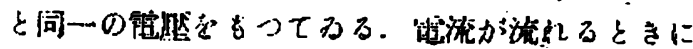

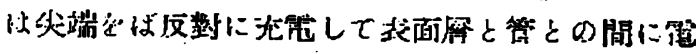

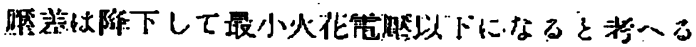

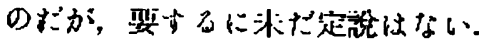

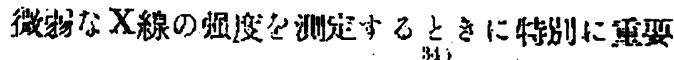
なのは，敢近 Groiger 及 Müllerによつで倠らん。

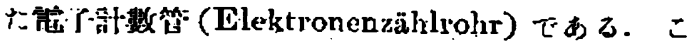

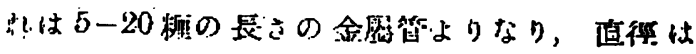

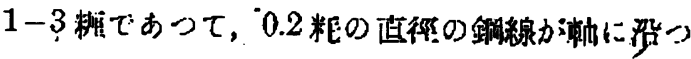

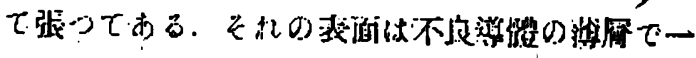

31) I. (jeiger, W. Müller, Physikal. Z. 2989.9 (1928) 


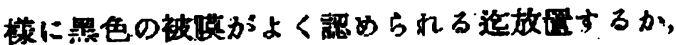

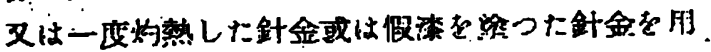

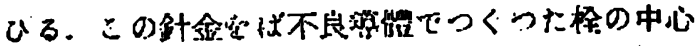

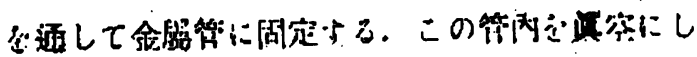

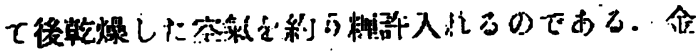

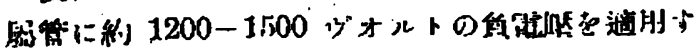

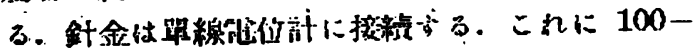

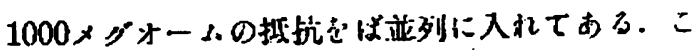

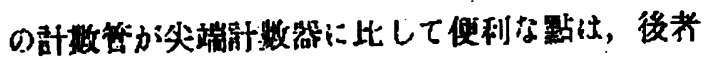

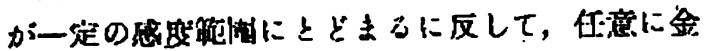

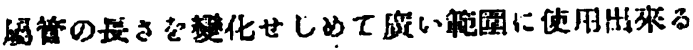

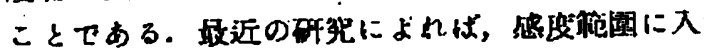

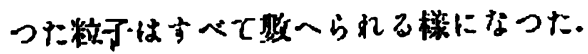

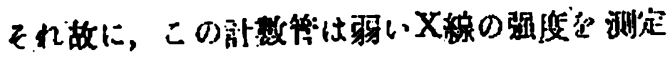

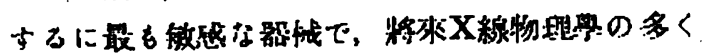

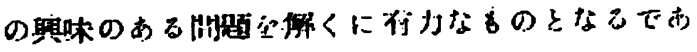
5j.

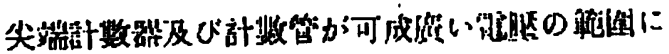

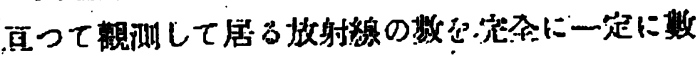

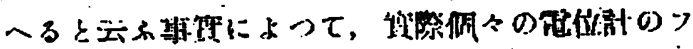

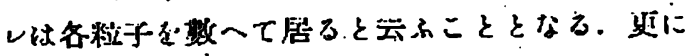

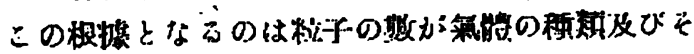

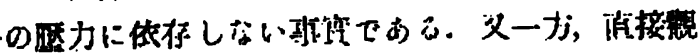

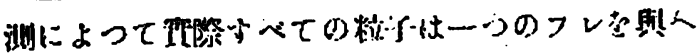
て括ると云ふことも知り得る場合ちする。

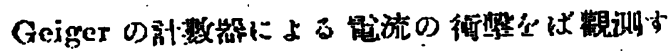

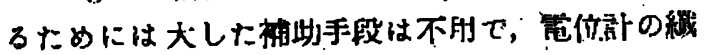
維のフレを眼て見て数へぬばまい。

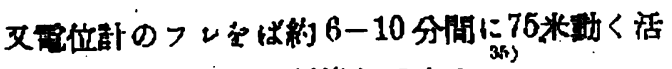

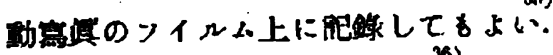

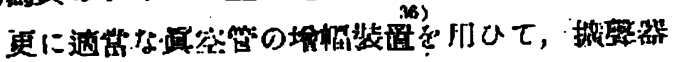

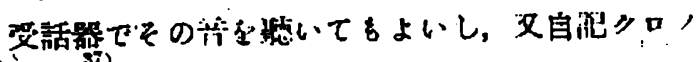
グラフ聝ひはブラウン想も用ひられる。

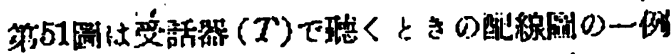
である。

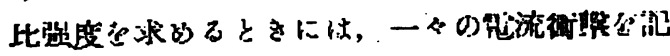

3ก) W. Bothe, H. Gciger: Z. Physik.32 644 (1925)

26) Kovarik : Phys. Rev. 13.153; 14179 (1919); 19433 (1922); 6426 (1915).

37) It. (ireinncher: $Z$. Physik 23361 (1924); th. Wulf; Physikal. Z. 26382 (1925); W. Kolhôrster: Physikal. Z. 26732 (1925)

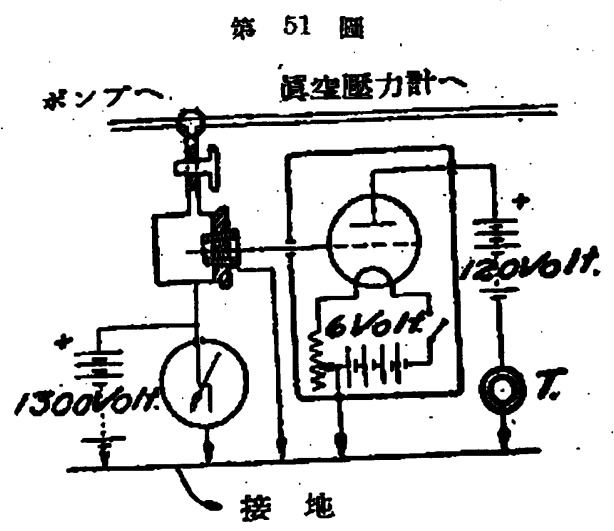

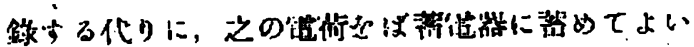

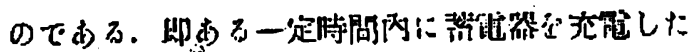

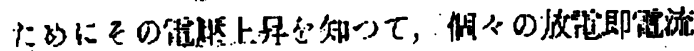

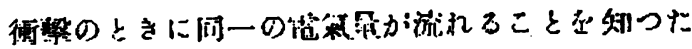

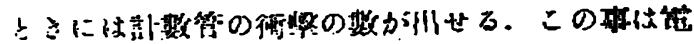

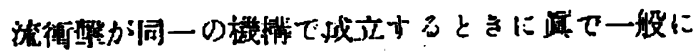

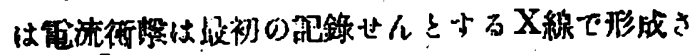
れたイオンの数に依存与る。

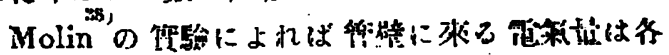
衙转に就てしらへたのに，1:2:3:4等の制合で

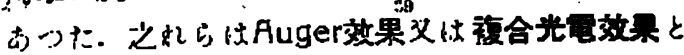

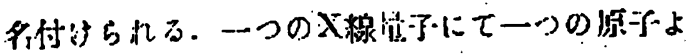

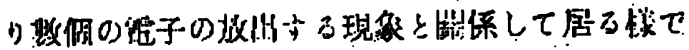

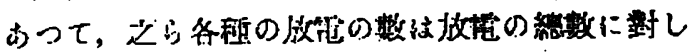

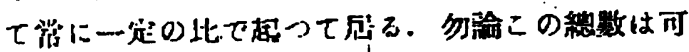

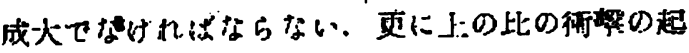

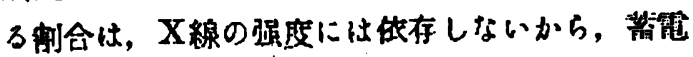

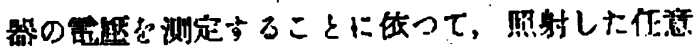

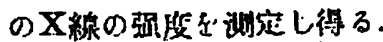

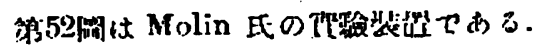

第 62 .

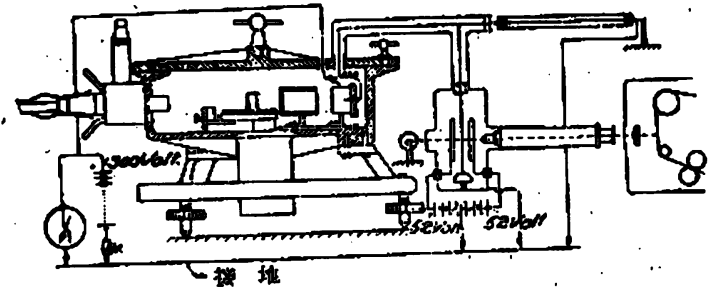

38) K. Molin: Ark. f.Mathem. Astr. u. Fysik. 19 A Nr 32 (1926)

39) Auger : $J$. phys. radium (6) 6205 (1925) 


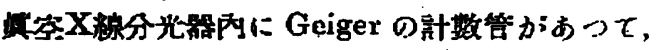

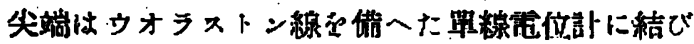
一うの高抵抗す通して接地されて居る。管位倽の

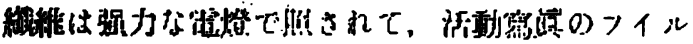
㕕与に像走結人て唇る。

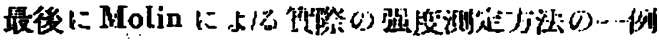

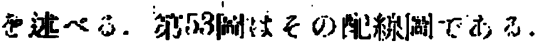

第. 5 : 触

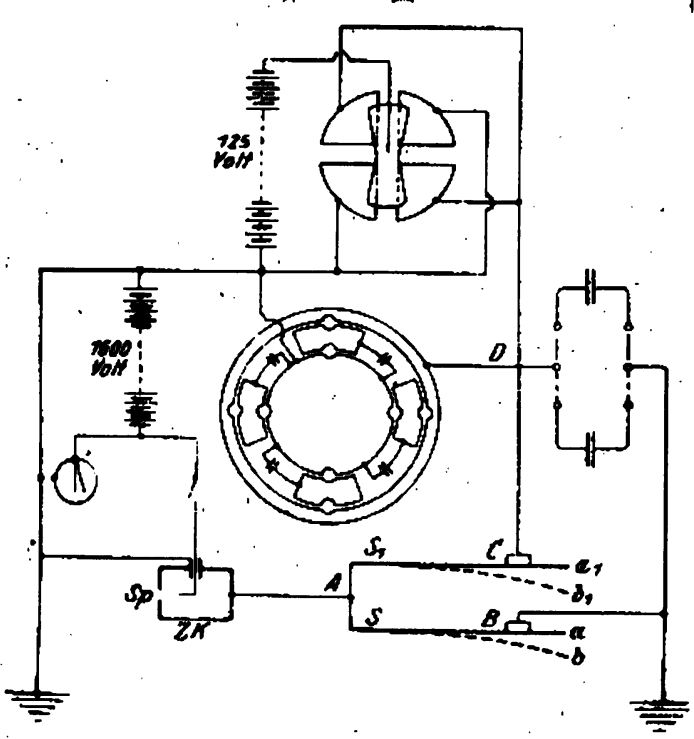

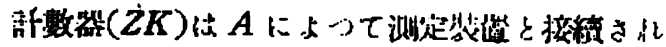

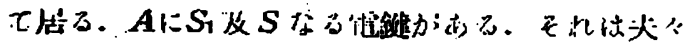

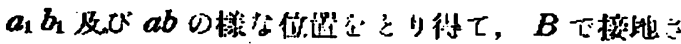

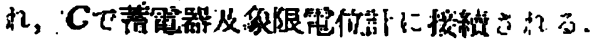

浿定の方法は

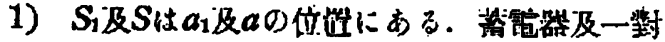
の象限は接地される。このとさ路位部の指針の零

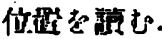

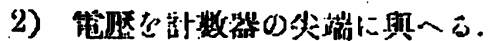

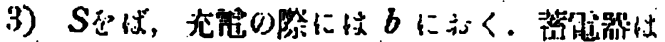

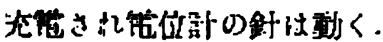

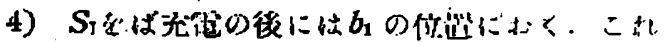
て回路は $Z K$ 上り造断される。

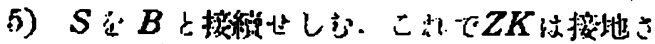

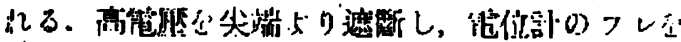
龍取る。

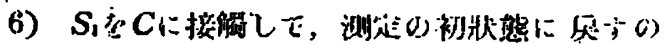
である.

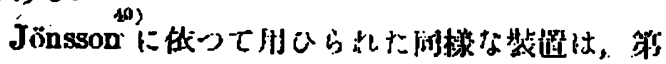

40) A. Jönsson: Z. Physik 36426 (1926)

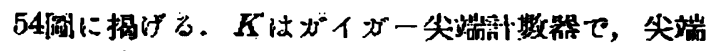
第 54 樋

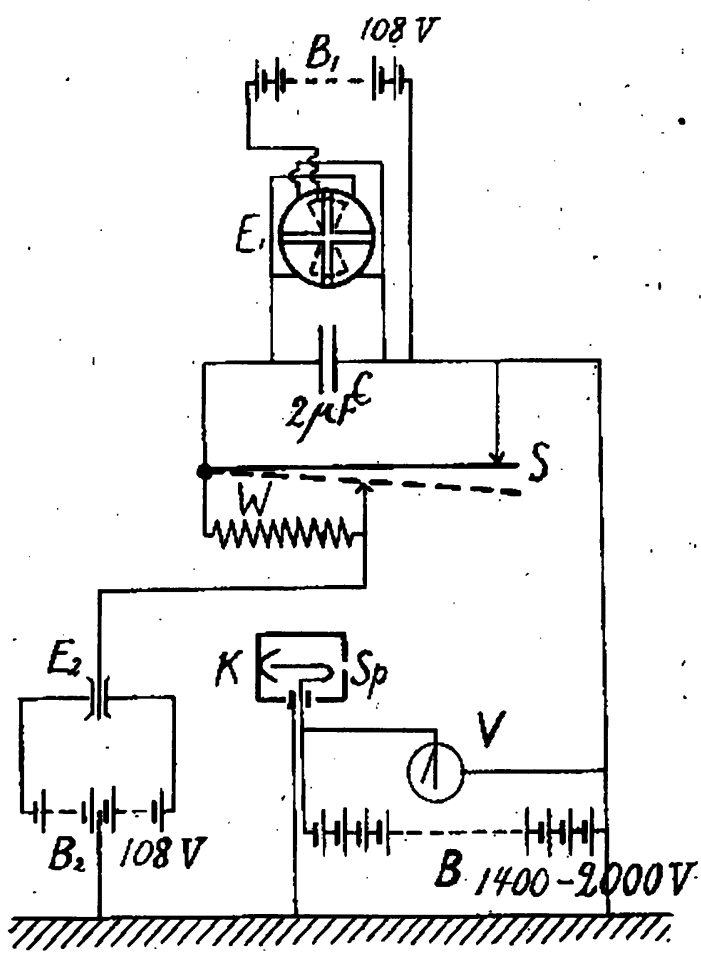

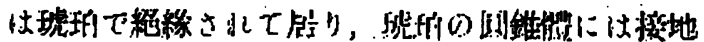

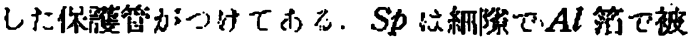

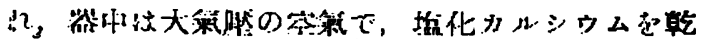

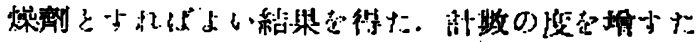

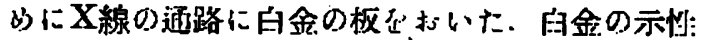

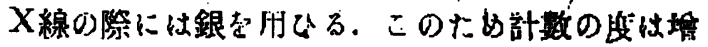
大し，弱いX線に適常である，尖端热より少し

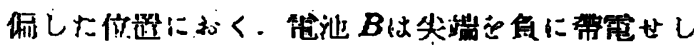

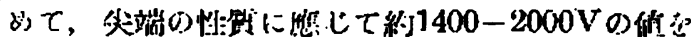

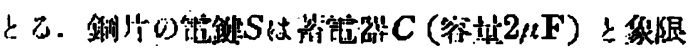

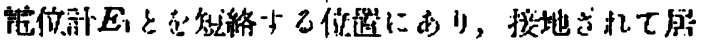

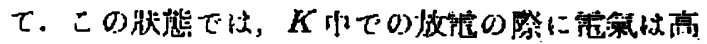

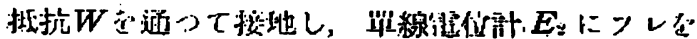

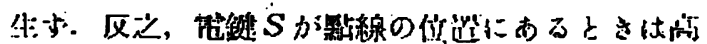

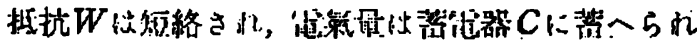

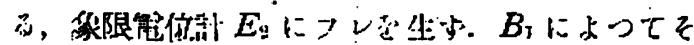

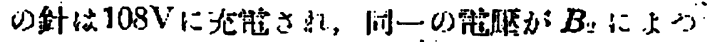

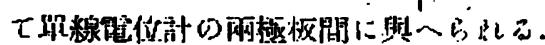

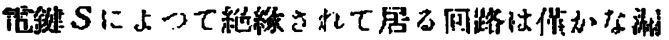

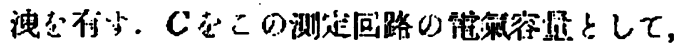

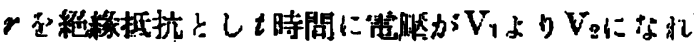


りとせば

$$
C r=\frac{t}{\log _{e} \frac{V_{i}}{V_{2}}}
$$

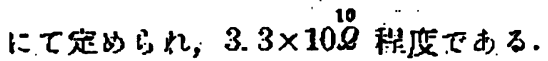

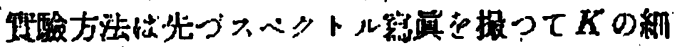

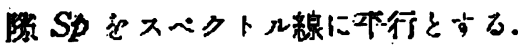

細隐の倨标 $0.13-0.25 \mathrm{~mm} の\}$ ，分光器の細陆 は0.06-0.13mmととうた。

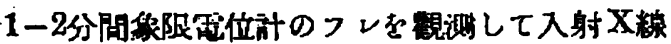

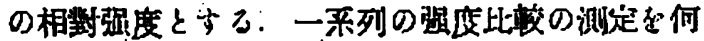

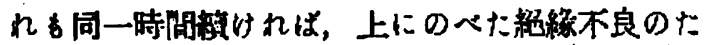

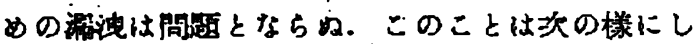

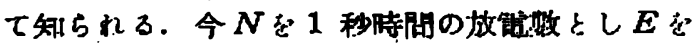

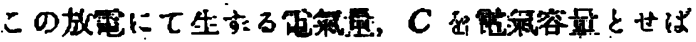

$$
N \cdot E \cdot d t=C \cdot d V+\frac{V}{r} \cdot d t
$$

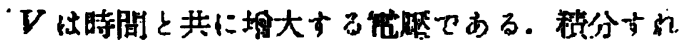
はீ

$$
V=N \cdot E \cdot r\left(1-\mathrm{e}^{\left.-\frac{\mathrm{t}}{\mathrm{Q} \cdot r}\right) \fallingdotseq \frac{E}{C} \cdot N \cdot t} \frac{t}{C}\left(1-\frac{t}{2 C r}\right)\right.
$$

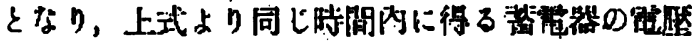

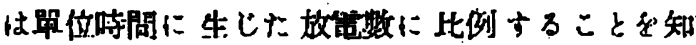

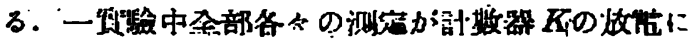

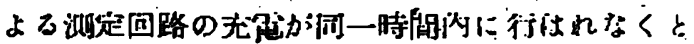
る上式によつて補正出來る。

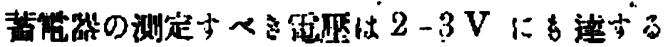

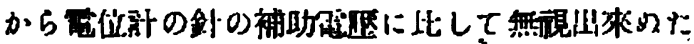
引に補正犯望す。

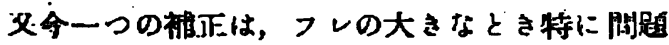
になるすのである．即上述の菁棈法にて、性，全紹

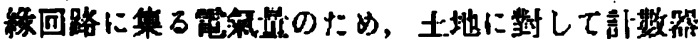

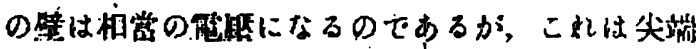

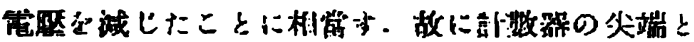

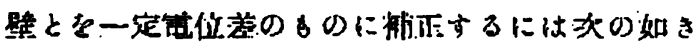
手綨 き识取る。

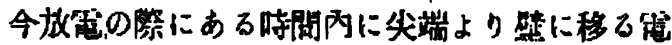
啭量とQと立れば

$$
Q=A \cdot n \cdot f\left(V_{8}-\frac{1}{2} V_{Z}\right)
$$

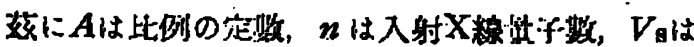

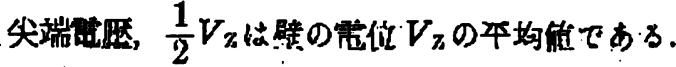
一才

$$
\boldsymbol{Q}=\boldsymbol{C} \cdot \boldsymbol{\varepsilon} \cdot \boldsymbol{a}
$$

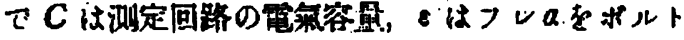
に换算する俰数と干。少

$$
V_{Z}=\varepsilon \cdot \alpha
$$

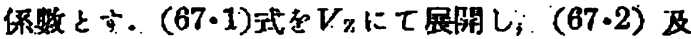

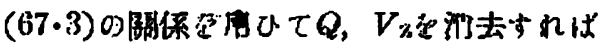

$$
a=\frac{A n}{C \cdot \varepsilon} f\left(V_{\mathrm{s}}\right)-\frac{A n}{\hat{C}^{-}} f^{\prime}\left(V_{\mathrm{s}}\right) \frac{a}{2} .
$$

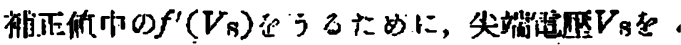

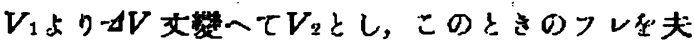
$\ll a_{1}, a_{n}, \dot{b}$ 测定した。

$$
\begin{aligned}
& a_{1}=\frac{A n}{C \cdot \varepsilon} f\left(V_{\mathrm{s}}\right)-\frac{A n}{C} f^{\prime}\left(V_{\mathrm{s}}\right) \frac{a_{\mathrm{I}}}{2} \cdot(67 \cdot 5) \\
& a_{\mathrm{s}}=\frac{A n}{C \cdot \varepsilon} f\left(V_{\mathrm{s}}-\Delta\right)-\frac{A n}{C} f^{\prime}\left(V_{\mathrm{s}}-\Delta\right) \frac{a_{3}}{2} .
\end{aligned}
$$

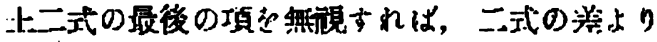

$$
f^{\prime}\left(V_{S}\right)=\frac{C \cdot \varepsilon\left(a_{1}-a_{2}\right)}{n \cdot A \cdot \Delta} \text {. }
$$

经.

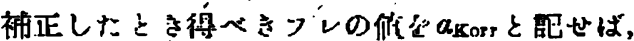
$(67 \cdot 4)$ より

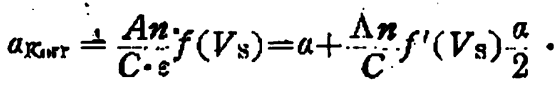

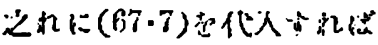

$$
\alpha_{\mathrm{Kurr}}=\alpha\left(1+\frac{1}{2} \cdot s\left(a_{1}-a_{0}\right)\right.
$$

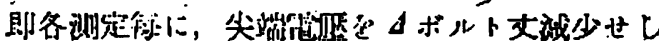

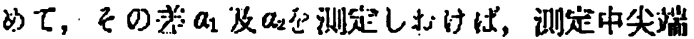

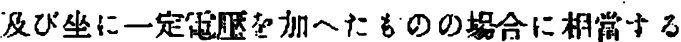

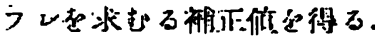

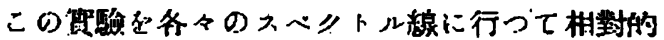

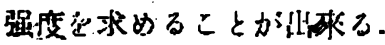

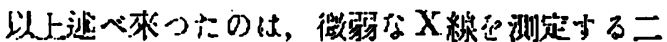

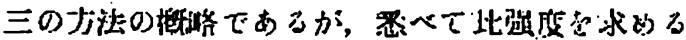

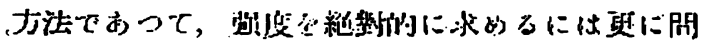
题纳難しくなるのて，只今注退へない。 